Article

\title{
Transportation and Air Quality Perspectives and Projections in a Mediterranean Country, the Case of Greece
}

\author{
Georgios C. Spyropoulos ${ }^{1,2}\left(\mathbb{D}\right.$, Panagiotis T. Nastos ${ }^{1, *(\mathbb{D})}$, Konstantinos P. Moustris ${ }^{2}(\mathbb{D}$ \\ and Konstantinos J. Chalvatzis ${ }^{3}$
}

1 Laboratory of Climatology and Atmospheric Environment, Department of Geology and Geoenvironment, National and Kapodistrian University of Athens, Panepistimiopolis, GR-15784 Athens, Greece; geospyrop@uniwa.gr

2 Laboratory of Soft Energy Applications \& Environmental Protection, Mechanical Engineering Department, University of West Attica, 250 Thivon and P. Ralli Str., GR-12244 Athens, Greece; kmoustris@uniwa.gr

3 Tyndall Centre for Climate Change Research, Norwich Business School, University of East Anglia, Norwich NR4 7TJ, UK; k.chalvatzis@uea.ac.uk

* Correspondence: nastos@geol.uoa.gr

check for updates

Citation: Spyropoulos, G.C.; Nastos, P.T.; Moustris, K.P.; Chalvatzis, K.J. Transportation and Air Quality Perspectives and Projections in a Mediterranean Country, the Case of Greece. Land 2022, 11, 152. https:// doi.org/10.3390/land11020152

Academic Editor: Shaojian Wang

Received: 20 December 2021

Accepted: 14 January 2022

Published: 18 January 2022

Publisher's Note: MDPI stays neutral with regard to jurisdictional claims in published maps and institutional affiliations.

Copyright: (C) 2022 by the authors. Licensee MDPI, Basel, Switzerland. This article is an open access article distributed under the terms and conditions of the Creative Commons Attribution (CC BY) license (https:// creativecommons.org/licenses/by/ $4.0 /)$.

\begin{abstract}
This study provides a thorough review and analysis of the evolution of the Greek vehicle fleet over the last $\sim 30$ years, which is next used for the generation of high granularity fleet projections, the assessment of associated air pollution and the estimation of relevant environmental benefits by 2030. The integrated methodology developed takes also into account vehicle clustering and the Brown's Double Simple Exponential Smoothing technique that, together with the adoption of COPERT-based emission factors, allow for the estimation of the anticipated emissions in 2030. Expected 2030 emissions levels suggest a reduction across all pollutants compared to 2018, ranging from $3.7 \%$ for $\mathrm{PM}_{10}$ to $54.5 \%$ for $\mathrm{NMVOC}$ (and $46 \%$ for $\mathrm{CO}, 14 \%$ for $\mathrm{SO}_{2}, 28 \%$ for $\mathrm{NO}_{\mathrm{X}}$ and $21 \%$ for $\mathrm{CO}_{2}$ ). We find that Greece is on track with national goals concerning the reduction of air pollution from the transportation sector, which designates the positive contribution anticipated by EVs and new, "greener" vehicles, and sets new challenges for the further improvement of the sector beyond the 2030 outlook.
\end{abstract}

Keywords: air pollution; transportation policy; vehicle fleet projections; electric vehicles; Exponential Smoothing; Greece

\section{Introduction}

The transportation sector is responsible for a significant share of air pollutant emissions, including those contributing to global warming and others affecting human health, with systematic exposure to even low concentrations of such pollutants potentially leading to chronic disease and early death [1]. To that end, and although technology advancements and overall progress in the field of modern vehicles have contributed considerably towards efficiency improvement, and thus emission reduction, the transportation sector in Europe is still found responsible for a significant share of the overall GHGs emissions, in the order of $20 \%$ [2]. What is more, despite that the sector produces a lower quantity of certain pollutants than other sectors, the sector impact is actually of higher risk. This is due to the fact that transportation-based air pollution is largely concentrated in high population density urban centres [3], which, interestingly, is the result of a vehicle use factor limited to $\sim 5 \%$, because vehicles remain idle (parked) for approximately $95 \%$ of the time $[4,5]$.

At the same time, and owing to the COVID-19 pandemic, travel behaviour and patterns have shown a dramatic change lately, with the use of public transport having decreased significantly globally [6]. In Greece for example, an extreme reduction has been noted in the use of buses and the subway, in the order of 30\% between September-October 2020 and 2021 [7]. Even though overall mobility has been restricted, the gradual recovery underway 
is based on the higher use of private vehicles leading to heavy peak hours traffic and respective pollutions. On another front, driven primarily by developing countries, the global vehicle fleet grows steadily with projections suggesting that by 2038 , vehicles around the world will have exceeded 2.2 billion, compared with 1.31 billion in 2020 [8].

Such an increase, however, also features changes in trends concerning the type of vehicles. A similar change, is recorded in southern Europe (Italy, Spain and Greece), where two-wheel vehicles seem to have gained a market share over the last years. This can be explained by their lower procurement, maintenance and operation costs, and manoeuvring ability in heavy traffic conditions. This comes down to an average ratio of $\sim 100$ motorcycles per 1000 city citizens for the above countries, which is higher compared to the European average (39.3 in 1994 and 67.8 in 2019). Two-wheel vehicles suggest one of the main solutions for the development of alternative transportation models and for tackling the problem of air pollution in urban centres [9]. This trend may be further supported with appropriate incentives, as well as with information campaigns, already carried out in major European cities like Barcelona, London and Vienna, where positive outcomes have been recorded [9].

Relevant to the analysis above, it is well accepted that the greatest share of air pollution in the urban environment derives from the transportation sector $[10,11]$. In recent years, significant effort has been devoted to the study of impacts, as well as urban air pollution reduction strategies [12]. One such strategy refers to the introduction of e-mobility and the use of zero-emission vehicles [13]. At the same time, the systematic monitoring of air pollution in the urban environment is an important step towards the effective assessment of air pollution [14]. The e-mobility sector includes a broad range of technological solutions, i.e., from EVs to HEVs and PHEVs [15]. Regardless of that however, environmental performance of vehicles relates to the characteristics of the supply source, and thus, for the e-mobility sector to contribute to the reduction of air pollution, electricity consumed should derive from RES [16]. Given the above, relevant strategic targets focus on two main directions. The first relates to the reduction of emissions per vehicle, with the use of anti-pollution technologies and more environmentally friendly fuels, which comes down to policies that have in past promoted a low-emission vehicle fleet [17], the use of natural gas as supply fuel [18], the introduction of FCEVs [19] and the use of biofuels or mixtures of biofuels and conventional fuels [20]. The second direction relates to the active involvement of citizens, called to embrace progressive policies and education with regards to, e.g., the reduction of maximum traffic speeds [21], or the limited use of conventional vehicles [12], etc. Life-cycle considerations come into play, taking into account the pollution relating to the different stages of vehicle production, shipment, raw material extraction, spare part development, recycling, etc, with the availability of raw materials potentially introducing additional geopolitical challenges [22].

On top of that, heavy traffic results to increased fuel consumption and air pollution from internal combustion vehicles, with an immediate impact on other aspects of everyday life, such as the reduction of productive time for vehicle drivers [23]. Such impacts are further aggravated by the fact that road networks in metropolitan cities, like Athens in Greece, are congested to a large extent. Therefore, effective congestion management requires extensive use of public transport and pollution emissions can be reduced with the "immediate" introduction of zero-emission vehicles for private and public use. Nevertheless, in terms of policies and their implementation, transition is complex, with a series of emerging societal implications.

Indeed, private vehicle ownership and use, as a way of living, has been highly valued societally [24], in contrast to aspects of sustainable development and living quality [25] in urban ecosystems. Recent studies however [26], indicate that concerns are growing with regards to issues such as the development of green urban settings and environmental justice, against the direction of expanding road networks and private vehicle use.

Alongside the above, the transport sector is undergoing a significant transformation based on new technological trends such as electrification, autonomous vehicles and micro- 
mobility vehicles. Therefore, the need for an in-depth study of the sector, its growth and quality trends, particularly with a focus on private vehicles, is essential to inform effective planning. On top of that, the association between atmospheric pollution and the transportation sector is of increased research interest over the last decades, with the relevant body of literature constantly evolving and providing a wealth of data, methodologies and models, both at a national and an international level.

One such notable study was carried out for Greece, capturing the period between 1992 and 2000 [27] and providing a detailed analysis of $\mathrm{CO}_{2}, \mathrm{CO}, \mathrm{NO}$ and NMVOC evolution, on the basis of the COPERT methodology (Computer Program to calculate Emissions from Road Transport). The specific methodology, being the reference method in this field, was developed in the context of the CORINAIR program, under which consistent and transparent monitoring of emissions is conducted for the European regions since the 1980s [28]. In more detail, the study examined the relation between vehicle fleet growth, substitution of older vehicles with new-at the time-catalytic converter vehicles and the relevant changes in the generation of atmospheric pollutants. Results obtained from the study indicated a considerable increase in emission levels between 1992 and 2000, specifically $68 \%$ in $\mathrm{CO}_{2}, 52 \%$ in $\mathrm{CO}, 28 \%$ in $\mathrm{NO}_{\mathrm{x}}$ and $39 \%$ in NMVOC, which designated the largest (negative) effect of fleet expansion against the positive effect of introducing catalytic converter vehicles.

In a following study [29], it was shown that in 2000 the local transportation sector of the two major cities of Greece, i.e., Athens and Thessaloniki, was responsible for $70 \%$ and $50 \%$ of annual $\mathrm{NO}_{X}$ and NMVOC respectively. Next, in 2004, a national-scale program was launched by the Greek Government [30], to record in detail national emissions by sector and develop a dedicated database for the transportation sector, allowing for further categorization per different type of vehicle. Simultaneously, with the support of the European Monitoring and Evaluation Programme (EMEP), a spatial analysis of human and nature induced pollution was conducted [31], reflecting the significant contribution of the transportation sector. Specifically for the prefecture of Attica and for Athens, a further study [32] used a grid of $1 \times 1 \mathrm{~km}^{2}$, to show the role of the local transportation sector and its contribution to hazardous $\mathrm{CO}, \mathrm{NMVOC}$ and $\mathrm{NO}_{\mathrm{X}}$ emissions.

In the same context, the development of a computational system for the recording of human-induced air emissions in Greece was described in [33], where top down and bottom up approaches were applied, that together with GIS and SQL tools led to high frequency emission zone data for $\mathrm{CO}, \mathrm{NO}_{2}, \mathrm{NO}, \mathrm{SO}_{2}, \mathrm{NH}_{3}$ and NMVOCs for 2003.

Subsequently, research conducted for Greece in 1990-2009 showed a gradual decline in transport induced air pollution [34]. At the same time, the study quantified the positive contribution of the local passenger vehicle fleet upgrade, illustrating the negative effects brought by the older heavy-duty vehicles. The study underlined the criticality of vehicle engine specificities and called for the development of programs for the upgrade of existing vehicle fleets. In a relevant study from the same authors [35], for the same period, the COPERT IV methodology was adopted, together with a top-down approach, with results showing a reduction in the quantities of $\mathrm{CO}, \mathrm{NO}_{\mathrm{X}}$ and $\mathrm{PM}_{10}$. Next, using a similar methodology, i.e., the EMEP/CORINAIR and the COPERT IV, the impact of introducing EURO5 and EURO6 vehicles was evaluated and associated with the relevant fuel consumption. Further use of the same methodology for the highly populated area of Attica (Athens) looked at a bundle of scenarios while involving more technical parameters such as the average vehicle speed, type of fuel, fleet evolution, size of engine, etc [36,37]. In this context, one of the main conclusions reached was that the prefecture of Attica is responsible for a high share of the national emissions for $\mathrm{CO}, \mathrm{NO}_{\mathrm{X}}, \mathrm{PM}_{2.5}$, VOCs and NMVOCs, and also comprises the second most important regional source of $\mathrm{PM}_{10}$ emissions.

At an international level, the transportation sector is found to have a significant contribution to air pollution, and is often found to be the main source of $\mathrm{NO}_{\mathrm{X}}$ and $\mathrm{PM}_{\mathrm{X}}$ emissions [38]. Indicatively, in studies concerning Beijing [39], the COPERT III methodology was used, with results demonstrating transportation's role in urban emissions. Through the 
adoption of a bottom-up approach similar conclusions were drawn for Shanghai, where the transportation sector is considered to be the main driver of pollution, with further results yielding that $20 \%$ of emissions derive from vehicles' cold starts [40]. In India at the same time [41], heavy-duty vehicles, buses and the numerous two-wheel vehicles comprising the local fleet accounted for an outstanding $94.5 \%$ of the overall $\mathrm{CO}_{2}$ emissions at the national scale. Moreover, even in islands where stationary air pollution sources might be prevalent [42], older vehicles are the main source of $\mathrm{CO}, \mathrm{NO}$, $, \mathrm{SO}_{2}, \mathrm{PM}_{10}, \mathrm{CH}_{4}, \mathrm{NMVOC}$ and also $\mathrm{CO}_{2}$ [43].

The present study contributes to the body of literature on transport emissions by providing new insights for the Greek transportation sector, focusing on the previous and forthcoming decade. Specifically, this study:

- Analyses and provides a classification for passenger vehicle fleet data for Greece during 1990-2018.

- Forecasts results for the Greek passenger vehicle fleet in 2030, opening up a analytic approach to vehicle mix insights.

- Generates annual emission factors for major air pollutants and $\mathrm{CO}_{2}$ up to 2030, deriving from each subcategory of the passenger vehicle, enabling scenario building for policy making.

- Estimates annual air pollution and $\mathrm{CO}_{2}$ emissions up to 2030 for each classified subcategory of passenger vehicle.

Following this brief introduction, this manuscript continues with Section 2 that focuses on materials and methods used in this study. Subsequently Section 3 presents the results through a wealth of figures and tables. Section 4 discusses the results and their broader implications and, finally, Section 5 provides the concluding remarks.

\section{Materials and Methods}

\subsection{Mapping and Recording of Active Fleet}

The current study deals with the mapping of the total vehicle fleet in Greece from 1990 to 2030. As mentioned before, many studies intertemporally assess the Greek vehicle fleet, calculating and predicting its evolution, documenting the derived pollution, while also attempting to predict relevant future developments. In all respects, the main challenge is in reliable data collection, regarding the vehicle fleet and its characteristics. Concerning a country's fleet size, it is necessary to quantify all existing vehicles in circulation, all brand-new vehicles that are for sale through dealerships, all vehicles (brand-new or second hand) imported by individual traders or purchasers and, finally, all withdrawn vehicles (for various reasons such as aging, damage, stealing etc.). Therefore, the most important characteristics concerning a fleet are for each vehicle, its type and size, segment, age, fuel type, engine technology according to European standards (Euro 1 to 6) classification, engine displacement, and the annual mileage it travels.

For the case of Greece, data collection related to the vehicle fleet was accomplished by gathering information from the official competent bodies and via Government reports, for the period between 1990 and 2019. More specifically, the official data sources used in this study, correspond to the Ministry of Infrastructure and Transport [44], the Hellenic Statistical Authority [45], the European Commission's Mobility and Transport Publications [46], the European Automobile Manufacturers Association [47-50], the Hellenic Association of Motor Vehicle Importers-Representatives [51], Emisia Company (a spin-off company of the Aristotle University of Thessaloniki that uses COPERT, the EU standard vehicle emissions calculator in Greece [52]) and the $\mathrm{CO}_{2}$ Data Bank of the European Environment Agency [53].

Following the processing of the collected data, the overall fleet of vehicles for the year 2019 is briefly presented below, with specific data for Greece in relation to the average EU vehicle fleet:

- The total EU passenger car fleet exceeded 242.7 million and had an average age of 11.5 years old, while the growing size of the fleet continued, with a rise of $1.8 \%$ 
compared to 2018. Alternative powered cars (Hybrid, LPG, Natural Gas, all types of electric cars) were just $4.6 \%$ of the total EU car fleet. The oldest vehicle fleets were in Lithuania (16.8 years old), Estonia (16.7 years old), Romania (16.5 years old), while Greece was in 4 th place (16 years old), with an overall vehicle fleet of more than 6.4 million vehicles.

- $\quad$ The average vehicle ownership in the EU (motorization rates) corresponded to 569 cars per 1000 inhabitants, with Latvia having the lowest density (342 per 1000 inhabitants), Luxembourg had the highest (694 per 1000 inhabitants) and Greece had 489 cars per 1000 inhabitants, about 100 fewer than in 2018.

- $52.9 \%$ of all passenger cars in the EU used gasoline, while $42.3 \%$ used diesel. Another $0.8 \%$ were hybrid electric, $0.2 \%$ were exclusively electric, $0.2 \%$ were plug-in hybrids, and finally, the remaining 3.6\% used natural gas, LPG, etc. Greece with more than 5.2 million passenger cars, differed significantly from any other country, and had the highest share $(91.1 \%)$ in gasoline usage of all EU countries and the lowest share of diesel usage $(8.1 \%)$, while the share of electric vehicles (all types) was at the level of $0.5 \%$.

- There were more than 6.2 million medium and heavy-duty trucks in the EU, with an average age of 13 years. Notably, the oldest fleet operated in Greece, which had an average age of more than 21.2 years. Only $0.04 \%$ of all trucks in the EU had zero emissions, $97.8 \%$ ran on diesel and $1.3 \%$ on gasoline.

- The light commercial vehicles sector exceeded 28 million trucks, with an average age of 11.6 years, with $90 \%$ using diesel and only $0.3 \%$ being electric. Again, the oldest fleet operated in Greece, with an average age of 19.5 years.

- $\quad$ Finally, the bus sector that operated across the EU numbered 692,207 vehicles and had an average age of 11.7 years. A large percentage, in the order of $94.5 \%$, relied on diesel fuel, while only $0.6 \%$ were electric, with the oldest EU bus fleet operating in Greece, with an average age of 19.9 years.

Consequently, it is a fact that Greece carries particular features regarding the overall fleet of vehicles (more than 8.4 million vehicles) and also presents noticeable differences compared to any other EU country. Concerning large vehicles, Greece has the oldest fleet. Moreover, as already mentioned, the country's passenger car fleet is the 4th oldest, and uses mostly gasoline. To that end, Attica is the most populous prefecture of Greece, including also the city of Athens, i.e., Greece's capital. Figure 1 represents the main categories of the vehicle fleet mix regarding both Greece and Attica. As one may see, motorcycles account for about $19 \%$ of the fleet (17.6\% for Attica), while passenger vehicles correspond to more than $64 \%$ (almost $75 \%$ for Attica) of the fleet, and comprise the main focus of this study.

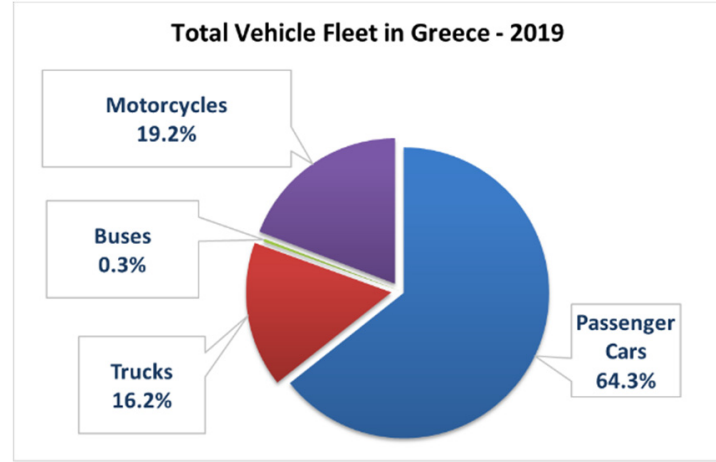

(a)

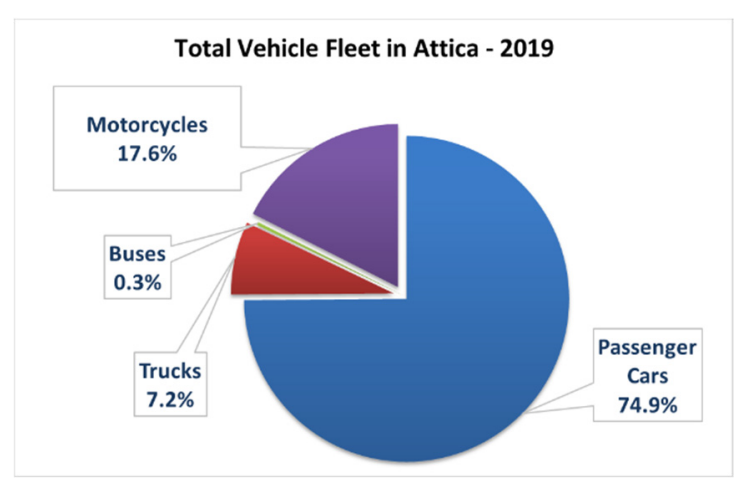

(b)

Figure 1. Total vehicle fleet mix for Greece (a) and Attica (b) for 2019.

Figure 2 demonstrates that Attica's vehicle fleet has reached almost $48 \%$ of the respective total of the Greek fleet, with almost 4 million vehicles. Taking into consideration the aggregate of vehicles (approx. 0.8 million) in Thessaloniki, which is the second largest city 
of Greece, it is obvious that these two urban centres define the general composition of the vehicle fleet, representing more than $50 \%$ of the country.

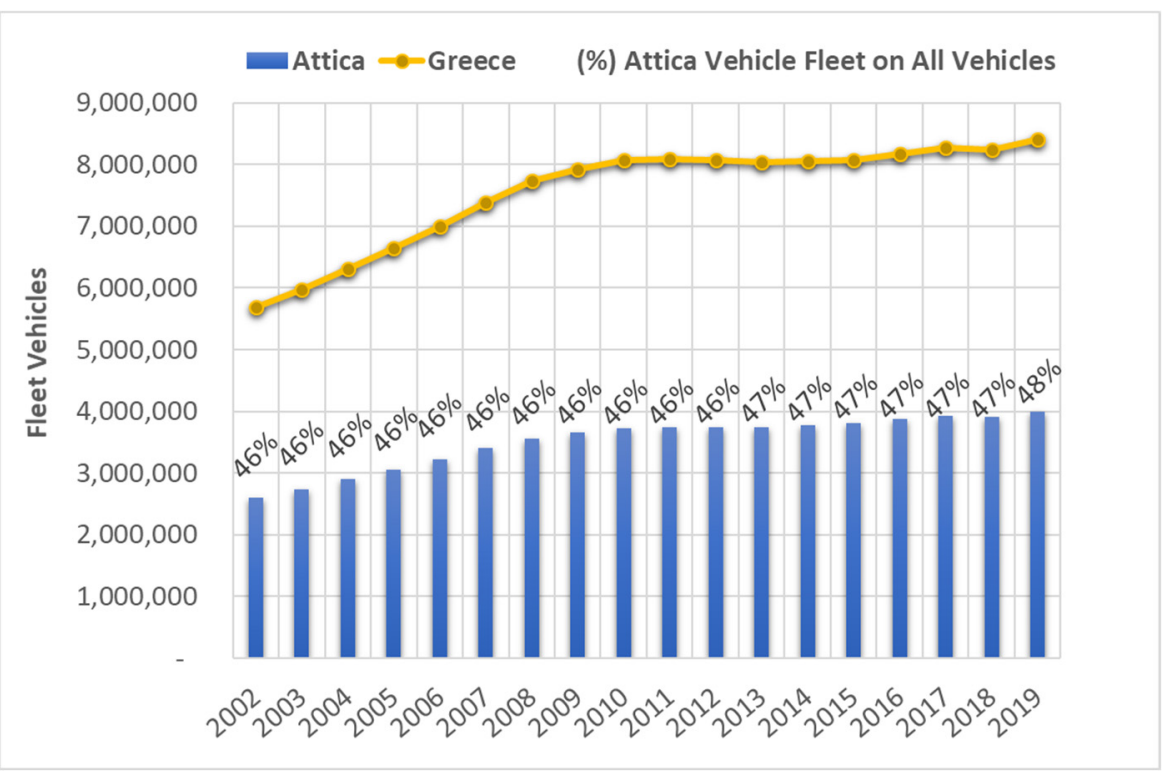

Figure 2. Overall fleet of circulating vehicles in Greece and in Attica, for time-period 2002 to 2019.

Finally, as it derives from Figure 3, it appears that in recent years, the regional share of passenger vehicles in Greece has remained almost constant. In particular, Attica's passenger vehicle fleet clearly had the largest share. More specifically, the category of passenger vehicles constituted $73.9 \%$ of the total number in Attica, $53.5 \%$ of the total number of passenger vehicles in the country and $34.4 \%$ of the total number of all country's vehicles. Therefore, and because passenger vehicles hold the largest share, it is this category this study focuses on. At the same time, it is clear that any changes in the use of passenger vehicles that takes place in Attica, essentially affects most of the fleet throughout the country.

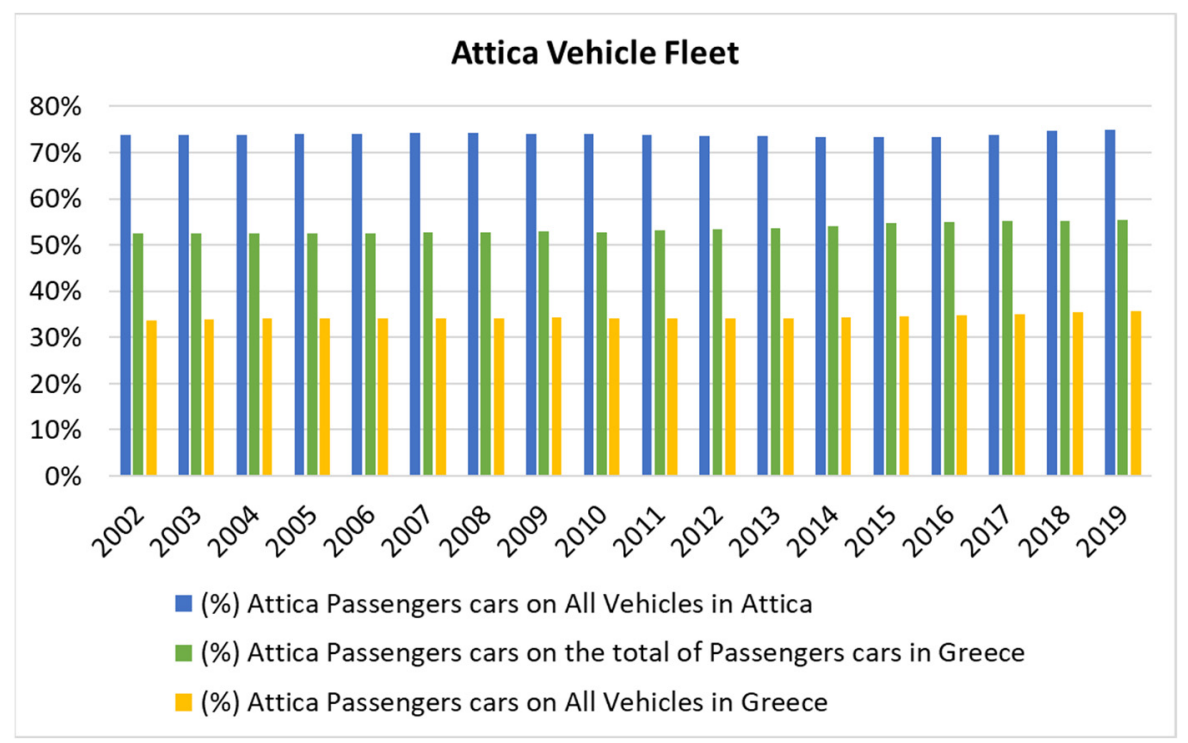

Figure 3. Percentage ratio of passenger vehicles in Attica, to the total number of vehicles in Attica, Greece and passenger vehicles in Greece. 


\subsection{Models for the Estimation of Transportation Sector Pollutants}

The main categories of models for the estimation of air emissions relating to the transportation sector include static (Top-Down) models and dynamic (Bottom-Up) models [54]. Both categories are used for the estimation of air emissions and for the assessment of atmospheric pollution in the transportation sector, under different scenarios and spatial scales.

Static models are next divided in two sub-categories corresponding to average speed models, like VEPM [55] and aggregated emission factor models like NAEI and MOBILE [56]. They are appropriate for the estimation of pollutants at broader scale, e.g., at national or city level, and they normally use emission factors per different fuel and pollutant together with average distance driven. They lack however, in terms of spatial analysis and are more effective for short period estimations.

Dynamic models are also divided into two sub-categories corresponding to traffic situation models, like HBEFA, ARTEMIS, COPERT and instantaneous models, like PHEM and MOVES [57,58]. They depend on the volume of available data and they account for more parameters like type of vehicle, vehicle speed, traffic conditions, hot/cold engine start, engine efficiency degradation in the course of time, etc. Moreover, in addition to their ability to provide long-term evaluations, they can also perform efficiently in short-distance and small-scale area problems.

In this context, the model that stands out is the COPERT model. The latter comprises a well-advanced, modern and widely used model amongst reference models used across the EU, with its early development dating back to the 80's [59,60], currently being in its 5th iteration [52]. Concerning pollution estimation, three different methods are used, associating with emission factors or fuel consumption or the percentage of the overall emissions, depending on the examined pollutants and the data available [61], and taking into account numerous parameters.

\subsection{Vehicle Fleet Forecasting Scenarios}

Rapid technological developments, including in the field of vehicles, make forecasting inherently challenging. Research agenda and political discourse on the most promising low emission vehicle engines are challenging as well [62]. At the same time, most technology development scenarios forecast that, by 2030, hybrid vehicles will present the higher demand, followed by fully electric vehicles, conventional fuel vehicles and fuel cell vehicles [63]. What matters most however, is that the growth of electric vehicles is followed by an increasingly "cleaner" electricity grid [64]. The Greek National Energy and Climate Plan foresees that by 2030, one out of three new vehicles will be electric in a fleet of approximately 5.5 million vehicles [65]. The forecasting approach adopted is based on the following basic steps [66]:

- Data collection and analysis: Requires data collection from cross-checked records and data cleaning for gaps and errors.

- Evaluation of demand parameters: Includes the identification and evaluation of internal and external parameters that might have a material impact to demand. Consideration will be given to technological development, political directives, affordability and others.

- Time horizon: Focus on near-term, mid-term and long-term demand forecasting.

- Forecasting evaluation: Forecasting scenarios will be evaluated as they are developed.

In addition, and in terms of scenario formulation, it is always important that the scenarios created are both broad enough and able to capture long-term trends in an effort to provide accurate forecasts. [67]. The Greek Government, has to that end, evaluated scenarios for the transport sector with software such as LEAP [68] and methods such as COPERT, focusing primarily on the vehicle fleet mix. As a result, the initial market conditions and the time of new vehicle sales define to a significant extent the modelling results [69]. A relevant step by step approach that has been proposed by [52,70], is shown in Figure 4. 


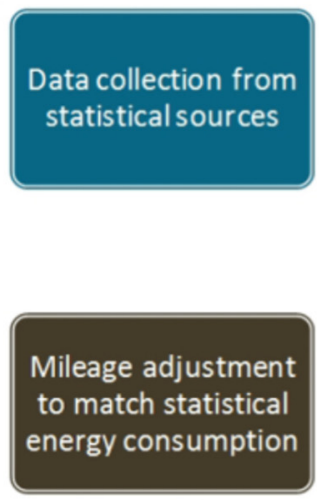

(energy balance)

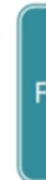

First processing step

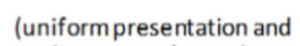
alignment of years by source for Greece)

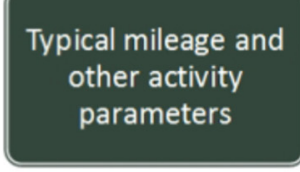

(e.g. U/R/Hspeeds and shares of Greek fleet mix)

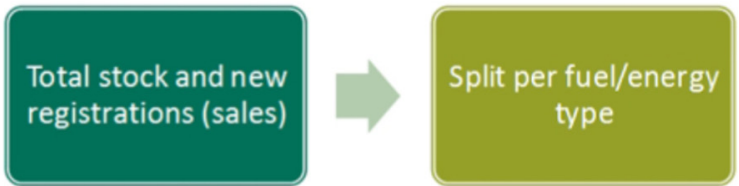

(for each vehicle category)
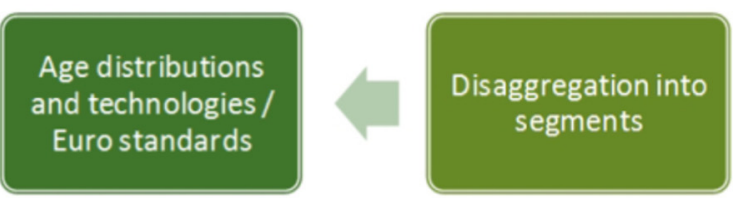

Figure 4. Vehicle fleet scenario development method. Reprinted with permission from ref. [70]. Copyright 2022 Elsevier.

Next, forecasting methods broadly fall into two categories [71,72]:

(a). Qualitative forecasting methods such as Delphi, Market Research, Consensus Methods, Visionary Forecast Prediction and Historical Analogy.

(b). Quantitative forecasting methods based on historical data with time series forecasting or causal models such as Multiple Regression Analysis, Econometric Models, Inputoutput Model, Economic Input-output Model and Leading Indicator Analysis.

Forecasting the vehicle fleet size until 2030 in the current study is based on the application of the Brown's Double Simple Exponential Smoothing method [73]. A quantitative method has been used to allow for greater reproducibility of the results, which would have not been possible with qualitative methods that can be heavily skewed by interviewee biases. Brown's Double Simple Exponential Smoothing was chosen instead of other quantitative methods mainly because it is suitable for the data and provides a straight-forward approach to eliciting results. Data includes timeseries of vehicle type, fuel type and EURO standards between 1990-2018. Time series smoothing is employed twice and takes into account the relevant trends, while Brown's method has been previously used successfully in vehicle fleet forecasting and air pollution studies [74-76]. Its application was initially based on quantitative historical data concerning the size and type of vehicle fleet and subsequently the forecasting of each of the fleet subcategories. Other smoothing methods are more suitable for a small number of variable values, which does not apply in our case. If given a time series that remains relatively stagnant over the examined period, then, the recommended method for the prediction of future values is the method of moving averages. On the other hand, if the time series examined features extra information in its most recent values, and thus may present a different trend, such as in our case, double Exponential Smoothing is preferable, like with the Brown method adopted. If the time series presents features of seasonality, which is not the case currently, a method such as Winters would fit our problem better.

The Exponential Smoothing method has been used to forecast the vehicle fleet in a single scenario. The Brown's method provides for statistical forecasting based on historical data and cannot produce multiple hypothetical scenarios, as the input is static past data. In this application, we consider the historical data from 1990 to 2018 to forecast the size of the vehicle fleet until 2030. Therefore, you cannot have high, medium and low scenarios, applying Brown's double simple Exponential Smoothing method. Moreover, as already mentioned, Greece's fleet has been affected by an economic crisis between 2009-2018 [77] with signs of recovery seen since 2019. Considering the first 19 years (1990 to 2008), there was an adequate linear trend that justifies the usage of Exponential Smoothing. However, due to the low fluctuation in the following years (2009-2018), the double smoothing 
approach was chosen. Moreover, it is common practice for researchers to assume in their basic approaches, linear forecasting behaviours in vehicle fleet development [78-81].

Therefore, Brown's Double Simple Exponential Smoothing method was applied for each one of the 28 different vehicle subcategories characterized by fuel type and standardization (Petrol (Prev Euro, Euro $1 \div 6$ ), Diesel (Prev Euro, Euro $1 \div 6$ ), Dual Fuel (Prev Euro, Euro $1 \div 6$ ), Alternative Fuel (Euro $4 \div 6$ ), PHEV /Plug in Hybrid Electric Vehicles (Euro $5 \div 6$ ) and $\mathrm{BEV} /$ Battery Electric Vehicles (Euro $5 \div 6$ ). However, in the case of BEVs, the smoothing methodology revealed a tremendous rise, with BEVs first appearing in the Greek market in 2015 (with 1 vehicle). Since 2016, although a small number of BEVs were added in the fleet up to 2018, the respective relative increase (percentage) was extremely high and thus misled estimations remarkably. Therefore, the authors choose to use data from the Energy Ministry. Next, the Prev Euro category refered to older vehicles preceding the introduction of Euro categorisation. Subsequently, every few years the new vehicles added into the fleet comply with the Euro 1, 2, 6 standards in force, hence delivering significant emission control improvements.

For every vehicle category time series, the Simple Exponential Smoothing method (Equation (1)) was applied as:

$$
\mathrm{V}_{\mathrm{t}}=\alpha \cdot \mathrm{Y}_{\mathrm{t}}+(1-\alpha) \cdot \mathrm{V}_{\mathrm{t}-1}
$$

where:

$V_{t}=$ smoothened time series values $V_{t}$. For $V_{0}=Y_{0}$ smoothened state of the time series estimates.

$\alpha=$ data smoothing factor for values $0 \leq \alpha \leq 1$; Smoothing weight for the level of the time series, is estimated with MS Excel solver.

$\mathrm{t}=$ time quantity as an annum, for $\mathrm{t}=1$ assume $\mathrm{Y}_{1}=\mathrm{V}_{1}$ and subsequently $\mathrm{t}=2,3, \ldots, n$. $Y_{t}=$ the observed value at time.

Subsequently, the smoothened time series values $\mathrm{V}^{\prime}{ }_{\mathrm{t}}$ were estimated with Equation (2):

$$
\mathrm{V}_{\mathrm{t}}^{\prime}=\alpha \cdot \mathrm{V}_{\mathrm{t}}+(1-\alpha) \cdot \mathrm{V}_{\mathrm{t}-1}^{\prime}
$$

where:

$\mathrm{V}_{\mathrm{t}}{ }_{\mathrm{t}}=$ the smoothed values of the time series resulting from the application of the second smoothing.

The forecast beyond $\mathrm{F}_{\mathrm{i}, \mathrm{t}+\mathrm{m}}$, for every $\mathrm{i}$ category ( $\mathrm{i}$ = petrol, diesel, dual fuel, alternative, PHEV, BEV), at $\mathrm{m}$ future time $(\mathrm{m}=1,2,3 \ldots, n)$ was given by Equation (3):

$$
\mathrm{F}_{\mathrm{i}, \mathrm{t}+\mathrm{m}}=\alpha_{\mathrm{t}}+\mathrm{m} \cdot \mathrm{b}_{\mathrm{t}}
$$

where:

$\mathrm{F}_{\mathrm{i}, \mathrm{t}+\mathrm{m}}=$ vehicle fleet $\mathrm{i}$ forecast for year $\mathrm{t}$ and every future time period $\mathrm{m}$.

$\alpha_{\mathrm{t}}=$ the estimated level at time $\mathrm{t}, \alpha_{\mathrm{t}}=2 \cdot \mathrm{V}_{\mathrm{t}}-\mathrm{V}_{\mathrm{t}}^{\prime}$.

$b_{t}=$ the estimated trend at time $t, b_{t}=\frac{\alpha}{1-\alpha} \cdot\left(V_{t}-V_{t}^{\prime}\right)$.

\section{Results}

\subsection{Forecasting of the Vehicle Fleet}

In Figure 5, the authors present data for the fleet size of petrol-powered passenger vehicles up to 2018, and forecasted data, for each vehicle category, with a prediction horizon that extends up to 2030 . 


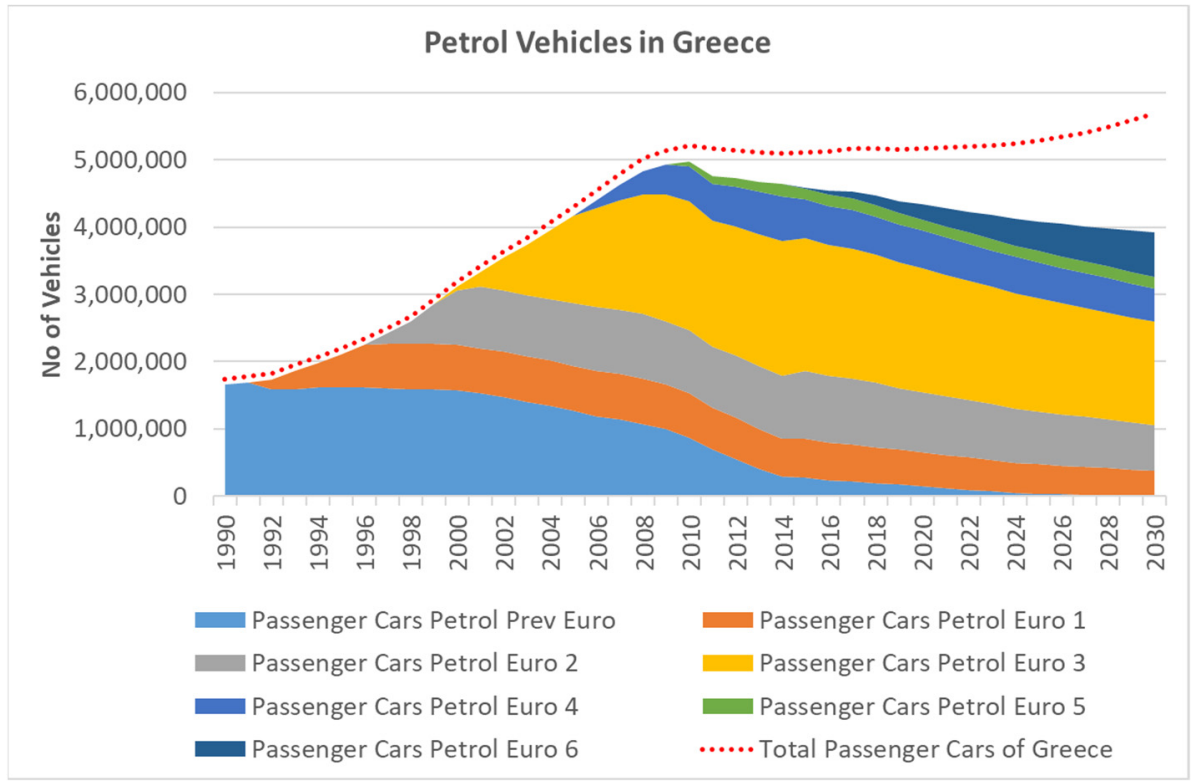

Figure 5. Time-evolution of the fleet size of petrol-powered vehicles and total passenger vehicles in Greece, 1990-2030.

A gradual reduction in the number of older vehicles is anticipated, alongside a small increase in vehicles of the most recent Euro category. Remarkably, Greece is the only EU country with such a large share (91.1\%) of petrol-powered vehicles. In absolute numbers, the petrol fleet size peaked during 2010, approaching a total of 5 million cars. Thereafter, that increasing trend stalled with the number of vehicles decreasing due to the economic crisis, in late 2009, while many consumers considered buying vehicles that used a different fuel type than petrol. The sales of new petrol-powered vehicles are expected to face a large reduction by and after 2025 , with significant parts of the fleet being replaced by vehicles that are based on more environmentally friendly technologies. It is important to note at this point that the structure of Greece's fleet has been largely affected by the economic crisis. The recession was deep and lasted way longer than that observed in other EU States. Greek households were confronted with significant reduction of their disposable incomes [82], hence replacing a vehicle became the lowest priority. The total number of passenger vehicles is illustrated with the red dotted line (Figure 5). In upcoming years, the fleet size is expected to increase, matching the trends of EU-28. The latter average number of passenger vehicles per capita faced a significant increase during the most recent years, a momentum that is not expected to conclude before 2035 [83].

In Figure 6, the fleet size of diesel-powered vehicles is presented. The fleet size is significantly smaller in comparison to the corresponding petrol-powered fleet. However, it comprises vehicles of newer technology, i.e., Euro 5 and Euro 6. The cause of dominance of these two categories stems from restrictions for private use of diesel-powered vehicles in Athens and Thessaloniki, the two largest cities of Greece. The ban was lifted by the end of 2011, for Euro 5 vehicles and newer ones.

By 2011, technology progressed significantly (with Euro5 vehicles), resulting in low diesel engine capacities, while, at the same time featuring similar performance characteristics to petrol-powered engines. In fact, according to the official technical characteristics, of the time, diesel-powered vehicles are more economical and more environmentally friendly than petrol equivalent vehicles. A claim that proved false (diesel gate scandal), by official reports. In particular, there were many occasions identified, where measurements recorded much higher emissions of pollutants than those reported by the automotive industry [84]. 


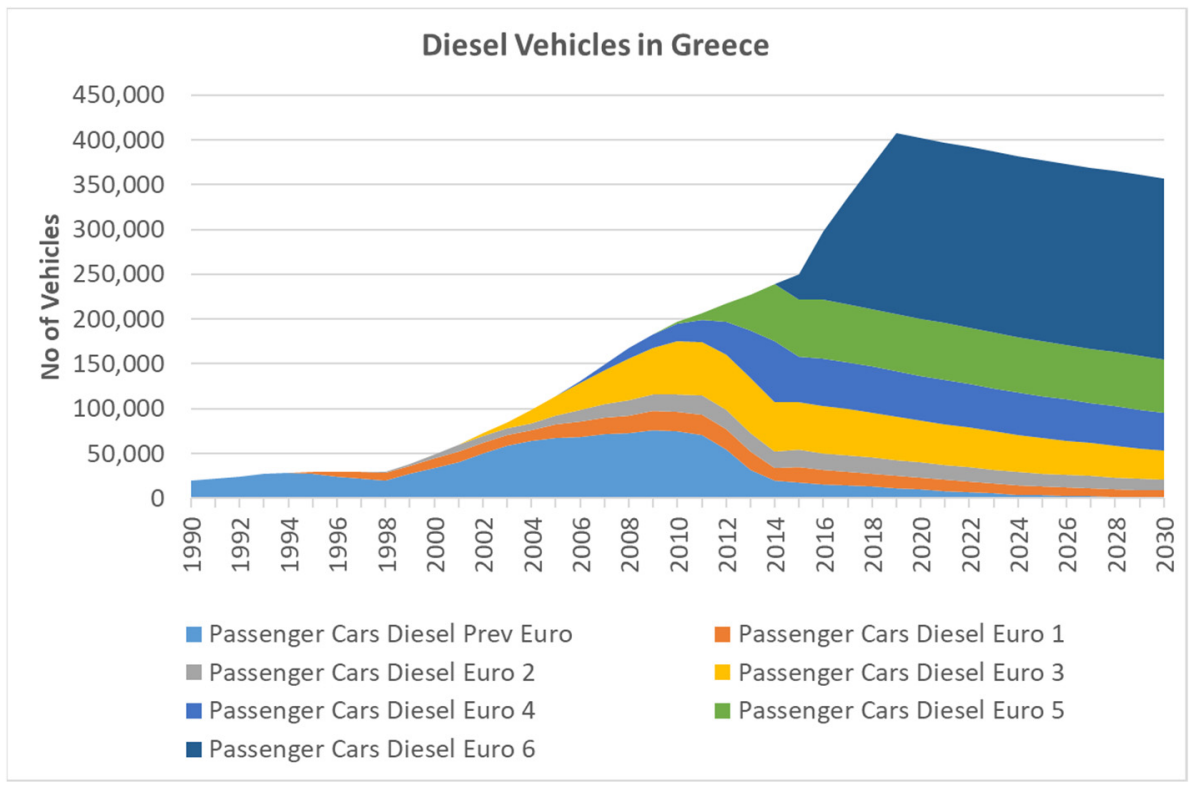

Figure 6. Time-evolution of the fleet size of diesel-powered vehicles in Greece, 1990-2030.

In either case, with respect to previous technologies, the vehicles performed better in almost every aspect. At the same time, diesel-powered vehicles were promoted by the industry and the EU, and gained significant market share [85]. That was the case, after 2009 , and that is the reason behind the significant fleet size growth becoming eminent after 2016. In absolute numbers, diesel vehicles peaked by 2019. Thereafter, the fleet size has been continuously decreasing. Given the international trends, which are against the use of diesel-powered vehicles, and that exhaust gases are subject to increasingly stringent rules, many manufacturers in Greece have already stopped importing diesel vehicles. Soon, the diesel vehicle fleet market will face a tremendous reduction, with newest vehicles numbers expected to maintain relatively steady. In addition, users that prioritize fuel economy are most likely to choose hybrid, electric or dual-fuel vehicles.

In Figure 7, authors present the time-evolution of the fleet size of dual fuel vehicles, which mainly comprises previous and recent generation vehicles that exploit LPG and natural gas as energy resource. Besides, LPG or natural gas, for the most part, these vehicles also utilize petrol. In Greece, this category was not very popular, until 2010. The main reason for that was the limited natural gas and LPG distribution network, which was accompanied by legal restrictions.

Nowadays, there is strong interest in dual fuel vehicles, with the latest models considered a more environmentally friendly option compared to conventional petrol or dieselpowered vehicles. This perception results from the reduced $\mathrm{CO}_{2}$ emissions, these vehicles achieve. Most consumers are familiar with this information because annual Greek vehicle tax is calculated exclusively based on $\mathrm{CO}_{2}$ emitted per $\mathrm{km}$. However, there is no consideration of $\mathrm{NO}_{\mathrm{X}}$ emissions which have been found to be higher in dual fuel vehicles [86-89]. Although, this category of vehicles emits higher emissions for some pollutants than conventional vehicles, this will not be quantitively noticeable in the near future. Most of the amount of expected reduction (in all pollutants) will come from the overall fleet renewal. Any new dual fuel vehicle that is added in the fleet, will be significantly better when replacing aging petrol or diesel vehicles. 


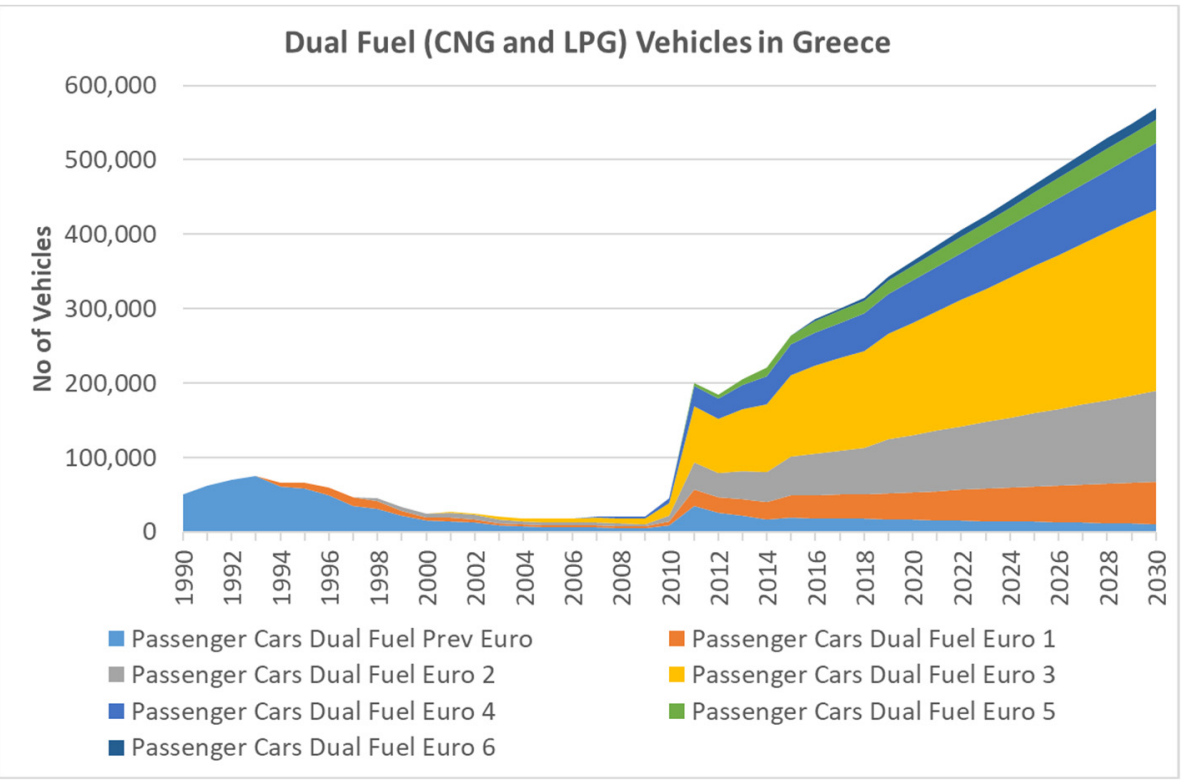

Figure 7. Time-evolution of the fleet size of dual fuel vehicles in Greece, 1990-2030.

Dual fuel vehicles are chosen by high mileage drivers as fuel cost has been notably cheaper. A large share of the owners of older or new generation petrol-powered vehicles chose to convert their vehicle, in order to take advantage of the less costly LPG and reduced maintenance. There has also been a large share of imported dual fuel vehicles by neighbouring countries, explaining the upward trend, even for older vehicles. Despite the increasing vehicle numbers, the fleet size remains quite small.

In Figure 8, the time evolution of alternative vehicles, PHEV (Plug in Electric Vehicles) and BEV (Battery Electric Vehicles) is presented. The alternative category consists of hybrid vehicles which for the most part utilize petrol and for the least part biofuels. Before 2015, the number of Euro 4 and Euro 5 (since 2000 and 2010 respectively) hybrid vehicles has been small and only started growing after 2015. Indicatively, in 2014, the total number of vehicles was only 6000, therefore, figure data start after 2015.

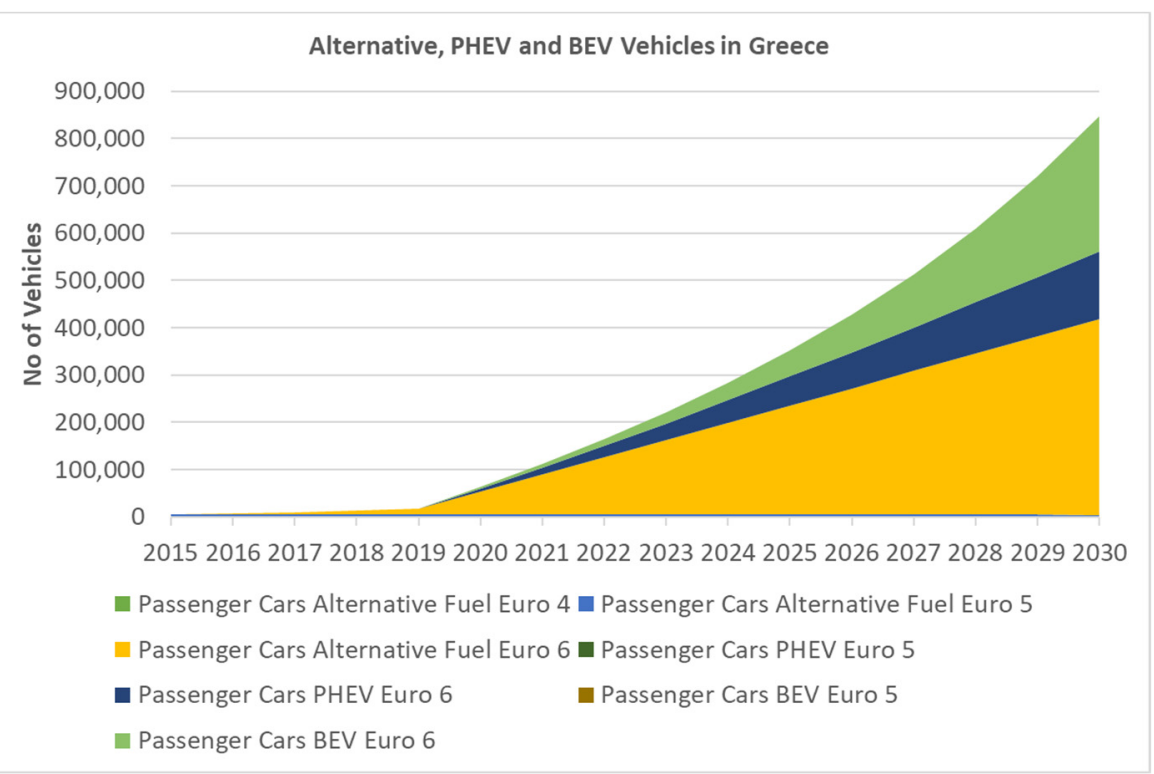

Figure 8. Time-evolution of the fleet size of alternative and electric passenger vehicles in Greece, up to 2030 . 
This vehicle category is expected to face the largest growth, due to the rapid battery cost reduction allowing for larger battery packs and driving range. Currently, in Europe, there are attractive incentives for electric vehicles. The fleet size is expected to be as large as 850 thousand vehicles by 2030 , with $49 \%$ belonging to the category of hybrid vehicles, 17\% being PHEV, and almost 34\% being BEV. With respect to Greece's 2030 overall fleet size, $14.9 \%$ will be hybrid, BEV and PHEV, with the latter two accounting for $7.5 \%$. In more detail, in Figure 9, the time-evolution trend of passengers BEV fleet in Greece until 2030, is presented. The number of EVs is captured with bars and using the second axis on the right, $\mathrm{BEV}$ penetration to the total passenger fleet is presented.

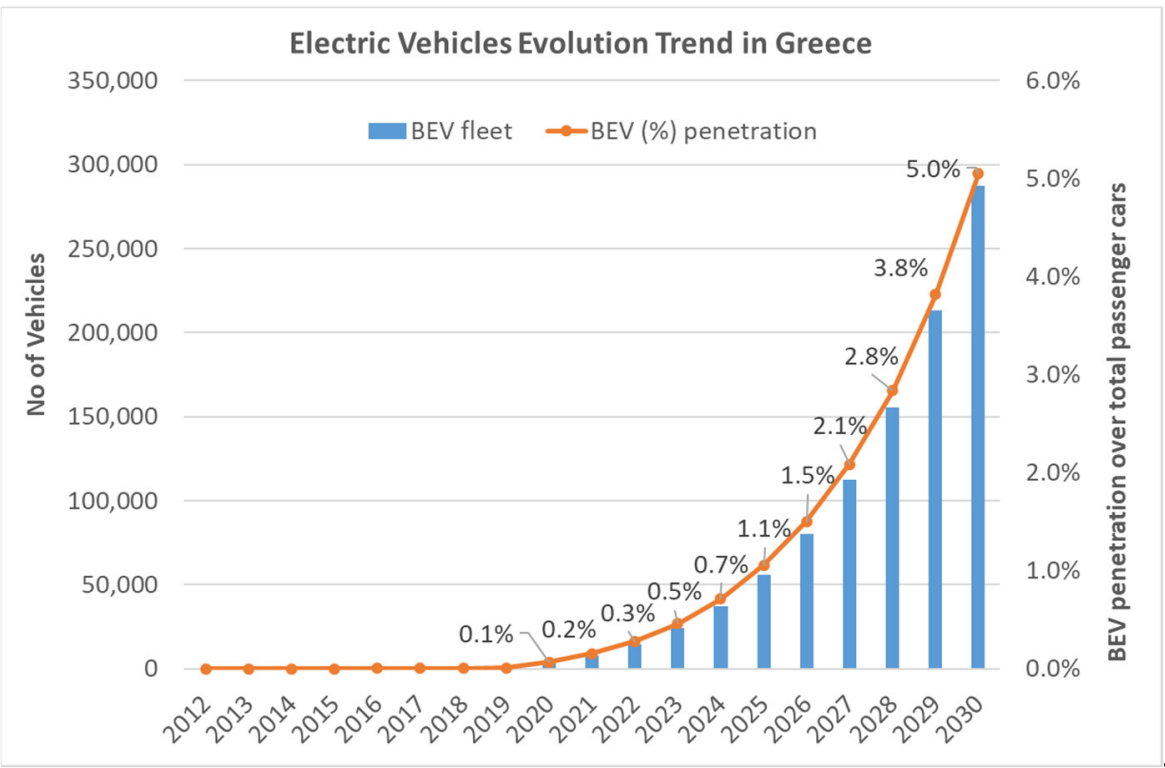

Figure 9. Time-evolution of passengers BEV fleet in Greece, until 2030.

Ultimately, the forecasted Greek passenger vehicle fleet size by 2030 shall approach 5.7 million units (Figure 10). The individual categories are grouped by fuel type, instead of technology of their power engine, allowing a more straightforward view. By 2030, the total vehicle fleet is expected to consist of petrol-powered vehicles by $68.8 \%$, diesel-powered vehicles by $6.3 \%$, dual fuel vehicles by $10 \%$, hybrid vehicles by $7.3 \%$, PHEVs by $2.5 \%$ and BEVs by $5.0 \%$.

\subsection{Prediction of Air Pollution Emissions}

Following forecasting the size of the passenger vehicle fleet, air pollutant emissions are estimated. The detailed fleet data include pollution parameters based on engine displacement, vehicle type, on the fuel and year, from 1990 to 2018 and per specific pollutant. Further pollution data were obtained from the EMEP/CORINAIR methodology and the utilization of the COPERT model as well as by the application of the Tier 3 methodological approach [90]. These data represent the official emissions of air pollutants from the transport sector in Greece. Hence, the base year regarding air pollutants prediction will be 2018.

Subsequently, vehicles were grouped according to engine displacement and vehicle segment so that they are similar to the previous 28 vehicle categories by fuel type and by emission standards, such as Euro 1,2, . , 6. The average air pollutant factors for every category were calculated in $\mathrm{gr} / \mathrm{km}$, according to the Tier 2 approach (COPERT) and were assumed to be fixed for future predictions. According to this assumption, any future new technology adopted, for internal combustion engines or in system exhausts (controlling or affecting the vehicle gases) regarding emissions, shall bring bigger reductions in every pollutant. Nevertheless, new $\mathrm{CO}_{2}$ emission targets were set for 2025 and 2030 [91,92], 
aiming to a $15 \%$ reduction for the period between 2021 and 2025 and by $37.5 \%$ for the period up to 2030. All calculations regarding new vehicles with the Euro 6 emission standard will account for the above-mentioned $\mathrm{CO}_{2}$ reductions.

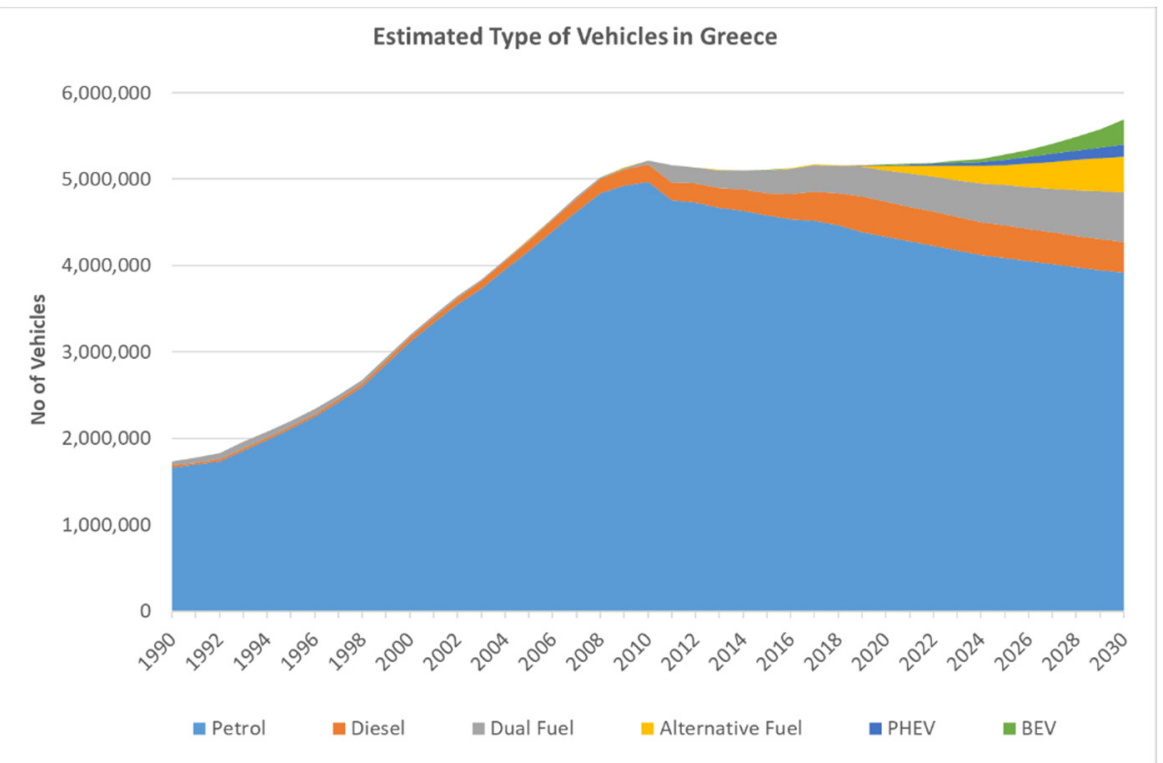

Figure 10. Number of passenger vehicles by fuel type in Greece, 1990-2030.

It should be stressed, that for the period between 1990 and 2018, the dataset includes information about the distance travelled by each vehicle subcategory. Therefore, the average distance travelled is calculated per category for each forecasted year, accounting for older categories' rate of change, the increased usage of new vehicles and the reduction trend of the distance travelled as vehicle fleet gets older. Below, Figure 11 presents the average annual distance travelled in Greece by passenger vehicles, which was produced by the average annual distance travelled by 28 different vehicle categories.

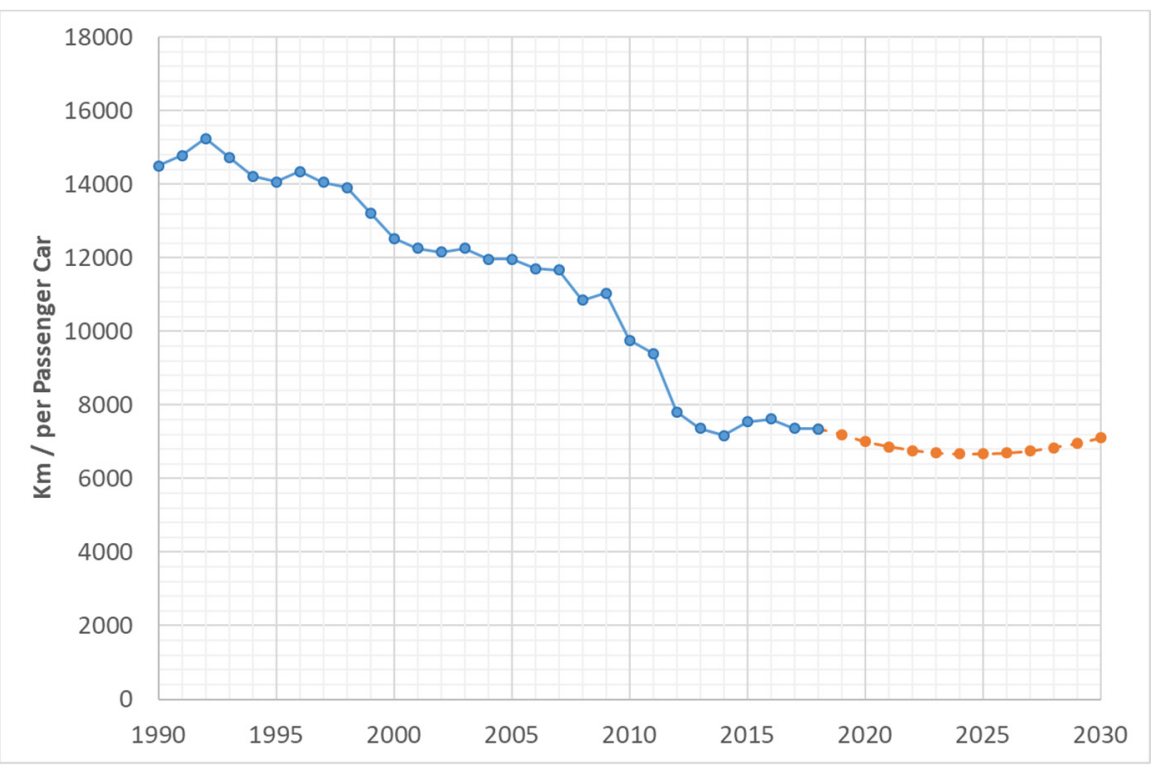

Figure 11. Average annual distance travelled (Km) in Greece by passenger vehicles, from 1990 to 2030.

The mean value was calculated by dividing the sum of each category's mileage by the total vehicle number. More precisely, according to data of 2018 the average annual travelled 
distance of a passenger vehicle in Greece was $7348 \mathrm{~km}$, while in 2030 the same value is expected to be $7104 \mathrm{~km}$. Furthermore, vehicle use has decreased since 1990, mainly due to the public transportation's evolution, the financial crisis that led to sharp decrease in vehicle usage and the increase in fuel prices and because people started using light vehicles for small distances. It should be noted that more than $50 \%$ of passenger vehicles run primarily in Attica region, whilst since 2000, when the Athens subway came into service, passenger vehicle use has decreased. Concurrently, although the average mileage seems to decrease as the vehicle fleet is ageing, after 2025, when older vehicle replacement takes place and more vehicles are added to the total fleet, an increase in vehicle use is noted. That prediction reflects on reality since drivers tend to use new vehicles more, with electric vehicles presenting notably higher use factors.

Furthermore, pollution estimations were produced by the sum of each vehicle fleet category, by fuel and technology (28 categories), multiplied by the pollutant coefficient $\mathrm{gr} / \mathrm{km}$, as well as by the annual average distance travelled. In every figure depicted below, the darker colour refers to data for the period between 1990 and 2018 and in lighter colour is the forecasted emissions until 2030.

Figure 12 depicts the total $\mathrm{CO}$ emissions from passenger vehicles in Greece for the period 1990 to 2030. One may notice that from 1990 to 2018 there was a reduction of $92 \%$, while from 1990 to $2030 \mathrm{CO}$ emissions are expected to reduce by $96 \%$. At the same time, according to the estimations for the period between 2018 and 2030 a $46 \%$ reduction is expected. Moreover, in 2030, responsible for the $23.7 \mathrm{kton}$ of $\mathrm{CO}$ emitted are petrol vehicles by $73.9 \%$, diesel vehicles by $2 \%$, dual fuel vehicles by $8.9 \%$, alternative fuel vehicles by $9.6 \%$ and PHEVs by $5.6 \%$, while BEVs have zero emissions.

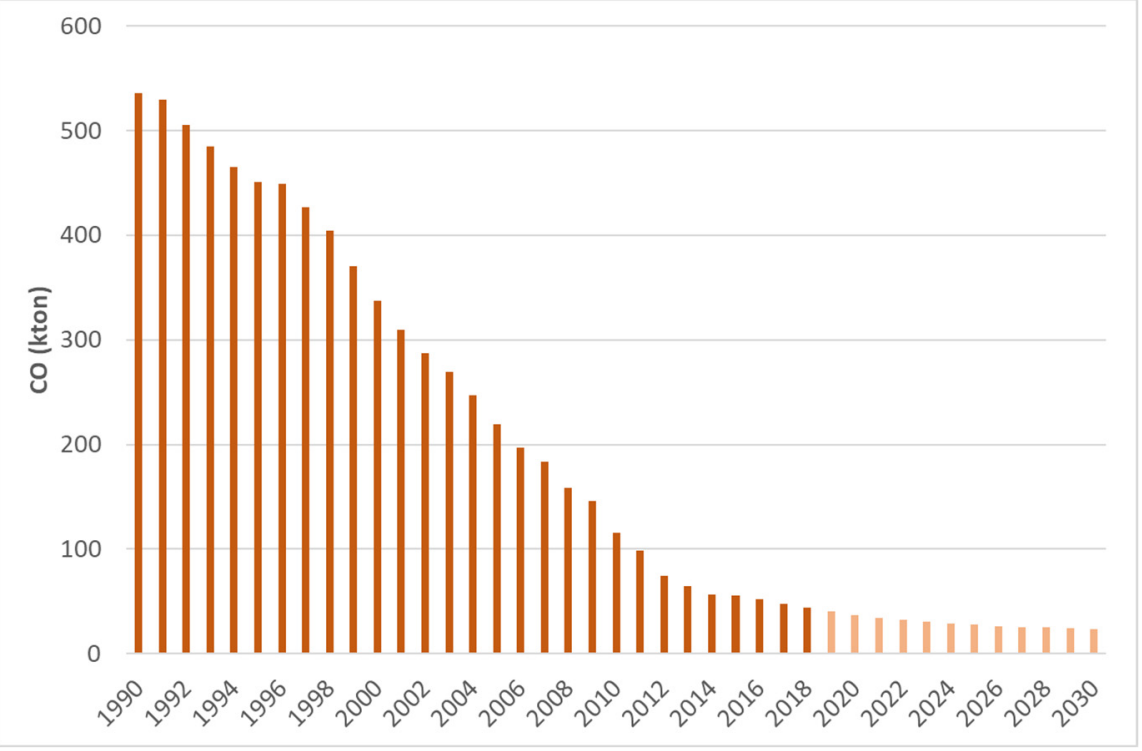

Figure 12. Total CO emissions from passenger cars in Greece for the period 1990-2030.

Figure 13 depicts the total $\mathrm{SO}_{2}$ emissions from passenger vehicles in Greece for the period 1990-2030. It is noteworthy that the presented steps reflect the successful introduction of gradually lower sulphur diesel based on EU Directives. To that end, a similar action plan had been implemented by the Greek government, concerning strategies (primary anti-pollution measures at the refinery) to prevent pollution and, as a result, did reduce sulphur levels in the fuel. In this context, for the period between 1990 and 2018, there is a decline in emissions of 99\%, while until 2030 the corresponding emissions are expected to decrease by $99.2 \%$. Meanwhile, from 2018 to 2030 , a total reduction of $14 \%$ is predicted. Finally, in 2030, from 30 tons of $\mathrm{SO}_{2}$ emitted into the atmosphere, $62.7 \%$ represents petrol vehicles, $17.2 \%$ diesel vehicles, $7.5 \%$ dual fuel vehicles, $12.6 \%$ alternative fuel vehicles and less than $1 \%$ PHEVs, while BEVs have zero emissions. 


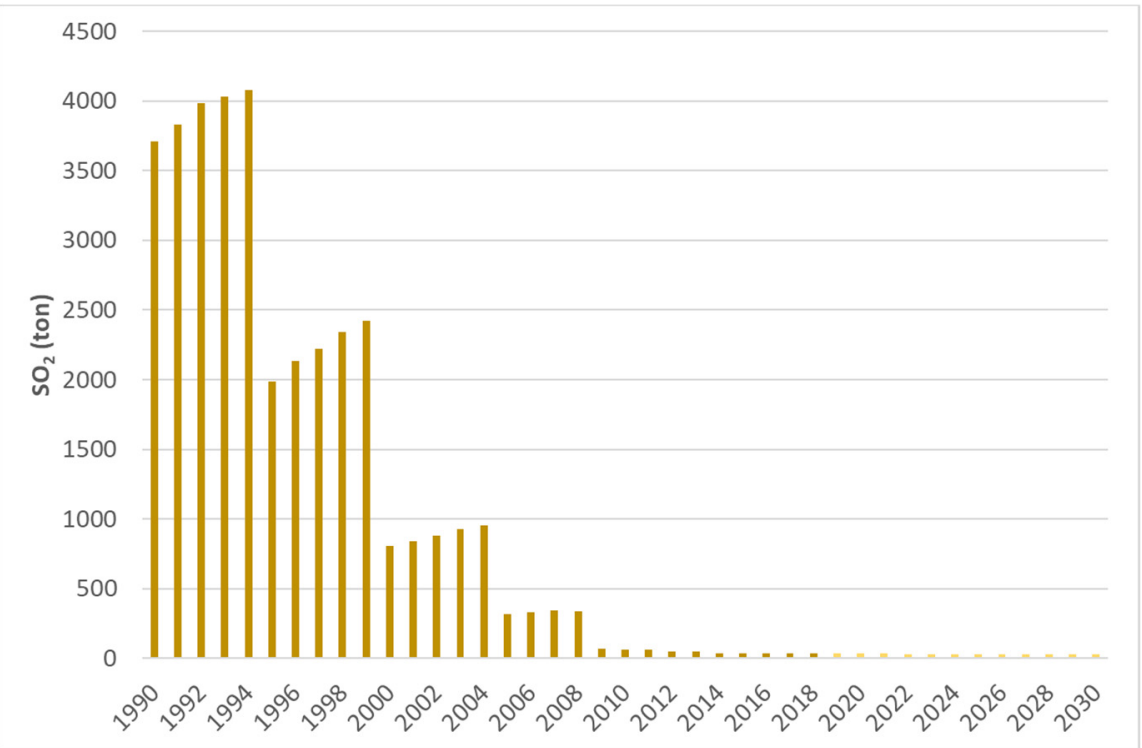

Figure 13. Total $\mathrm{SO}_{2}$ emissions from passenger cars in Greece for the period 1990-2030.

By the same token, in Figure 14 the total $\mathrm{NO}_{x}$ emissions from passenger cars in Greece are presented for the period 1990-2030. For the period between 1990 and 2018, there is an emission decline of more than $84 \%$, while until 2030 the corresponding emissions are expected to decrease by almost $89 \%$. Between 2018 and 2030 a total reduction of $28 \%$ is expected.

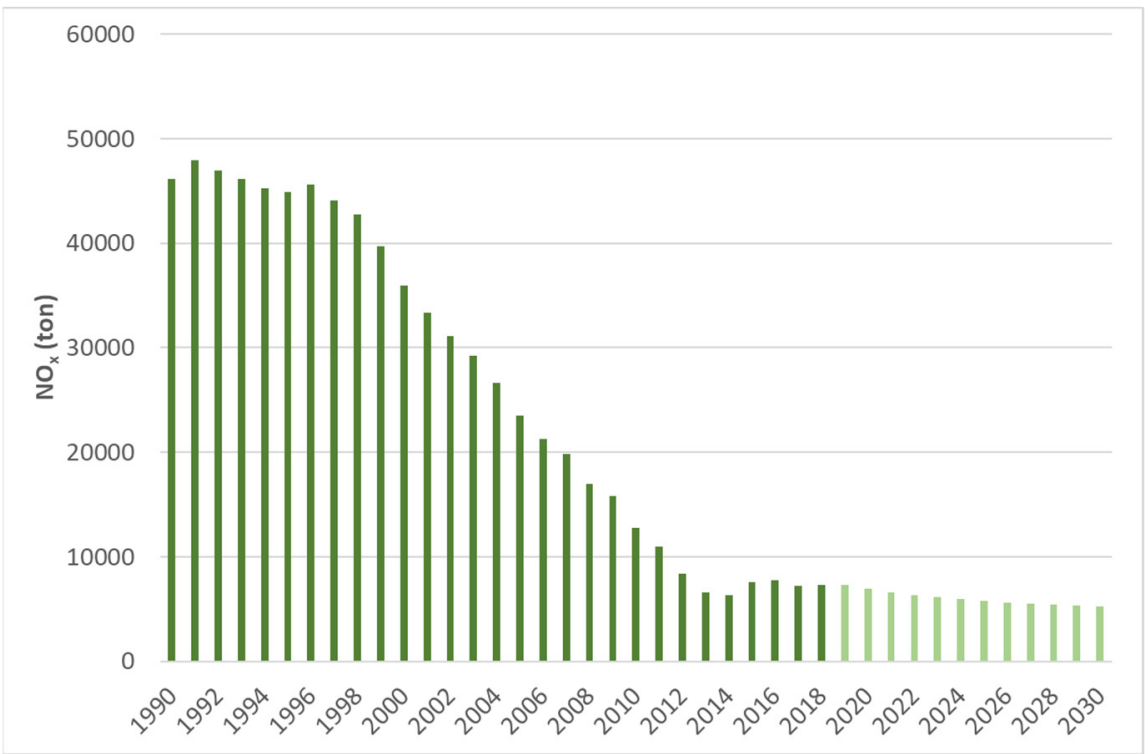

Figure 14. Total $\mathrm{NO}_{\mathrm{x}}$ emissions from passenger cars in Greece for the period 1990-2030.

The contribution of diesel vehicles to $\mathrm{NO}_{\mathrm{x}}$ emissions after 2014 is notable and is largely due to their growing market share. In 2030, $5.3 \mathrm{kton}$ of $\mathrm{NO}_{\mathrm{x}}$ will be emitted, out of which $24.6 \%$ will be attributed to petrol vehicles, $67.1 \%$ to diesel vehicles, $3.1 \%$ to dual fuel vehicles, $3.9 \%$ to alternative fuel vehicles and $1.3 \%$ to PHEVs, while BEVs have zero emissions.

Figure 15 depicts the total $\mathrm{PM}_{10}$ emissions from passenger cars in Greece for the period 1990-2030, including the non-exhaust $\mathrm{PM}_{10}$ (tyre and brake wear, road abrasion). For the period between 1990 and 2018, there is an emission decline of more than $12 \%$, while by 2030, the respective emissions are expected to be less than $15 \%$. Concurrently, for the predicted period, a total $\mathrm{PM}_{10}$ reduction of $3.7 \%$ is expected. Similar to Figure 13, a rise 
of $\mathrm{PM}_{10}$ is presented after 2014 due to an increased market share of diesel vehicles. While a gradual $\mathrm{PM}_{10}$ reduction is observed, after 2025, the total $\mathrm{PM}_{10}$ emissions will increase due to the ever-increasing vehicle fleet size. The above-mentioned observation is thoroughly explained in the discussion section. In 2030, out of the 1.03 kton of $\mathrm{PM}_{10}$ emitted, $49.4 \%$ will have come from petrol vehicles, $20.4 \%$ from diesel vehicles, 5.0\% from dual fuel vehicles, $15.7 \%$ from alternative fuel vehicles, $3.9 \%$ from PHEVs and 5,6\% from BEVs.

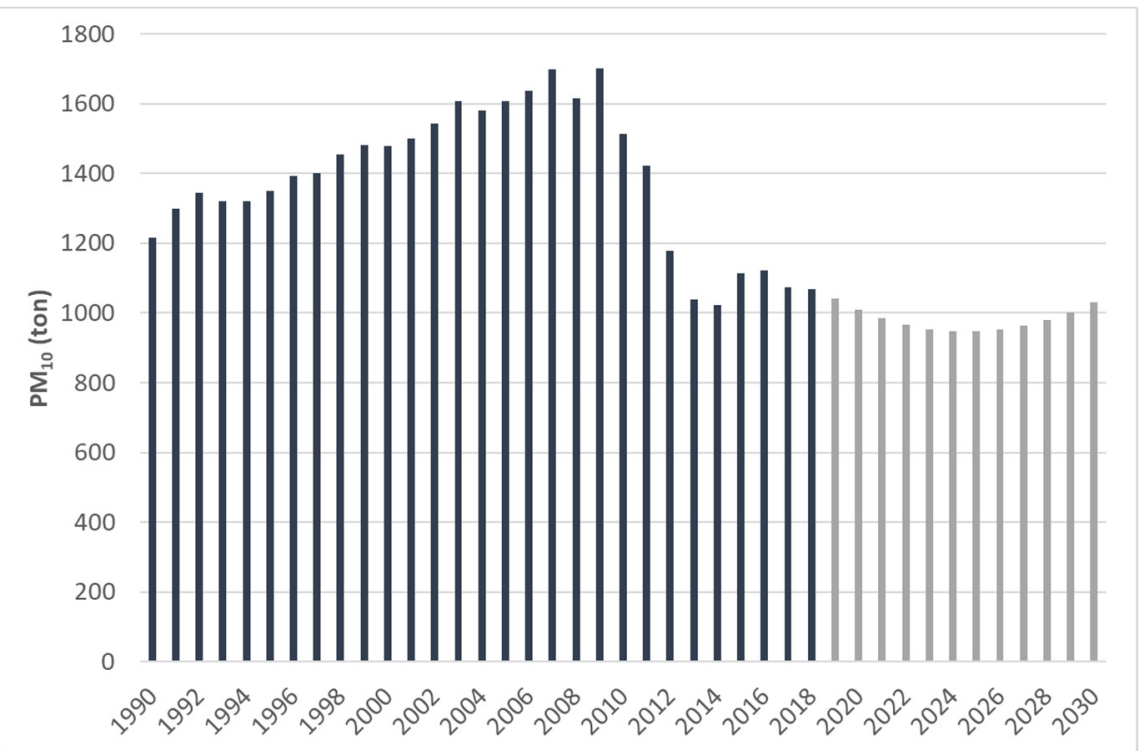

Figure 15. Total $\mathrm{PM}_{10}$ emissions from passenger cars in Greece for the period 1990-2030 including the non-exhaust $\mathrm{PM}_{10}$ (tyre and brake wear, road abrasion).

Figure 16 presents the total NMVOC (Non-methane volatile organic compounds) emissions from passenger vehicles in Greece for the period 1990-2030. NMOVCs present important chemical differences but behave similarly in the atmosphere, which is partly why they are grouped together in one indicator. Specifically, for road transport, they originate from the fossil fuel used and emissions can be significantly higher with cold-start engines. Incomplete fuel combustion, higher engine friction and catalyst inefficiency are some of the reasons for that. COPERT takes into account: vehicle technology, mileage fraction driven under thermally non-stabilised engine conditions (Hot-Cold start emissions), $\mathrm{km}$ share attributed to urban conditions (Urban - Rural - Highway), fuels different energy content, fuel energy balance, calorific and density value of the fuel, evaporation losses, activity data, energy consumption, annual $\mathrm{km}$ travelled, temperature dependent emission factor, fleet energy consumption a mileage correction factor, statistical and calculated energy consumption, adjusted mean activity values, emission degradation due to vehicle age, emission level of a fleet of brand new vehicles and degradation of the emission performance per kilometre. For the period between 1990 and 2018, there is an emission decline of more than $84 \%$, while by 2030 the respective emissions are predicted to fall by 93\%. Moreover, between 2018 and 2030, a total reduction of 54.5\% is expected. For as long as cleaner vehicles are increasingly introduced into the vehicle fleet, NMVOC emissions will continue to decrease. In 2030, out of the 4.75 kton of NMVOC emissions, $82 \%$ are expected to be from petrol vehicles, $0.6 \%$ from diesel vehicles, $4.0 \%$ from dual fuel vehicles, $13.4 \%$ from alternative fuel vehicles and less than $1 \%$ from PHEVs, while BEVs shall carry zero emissions. 


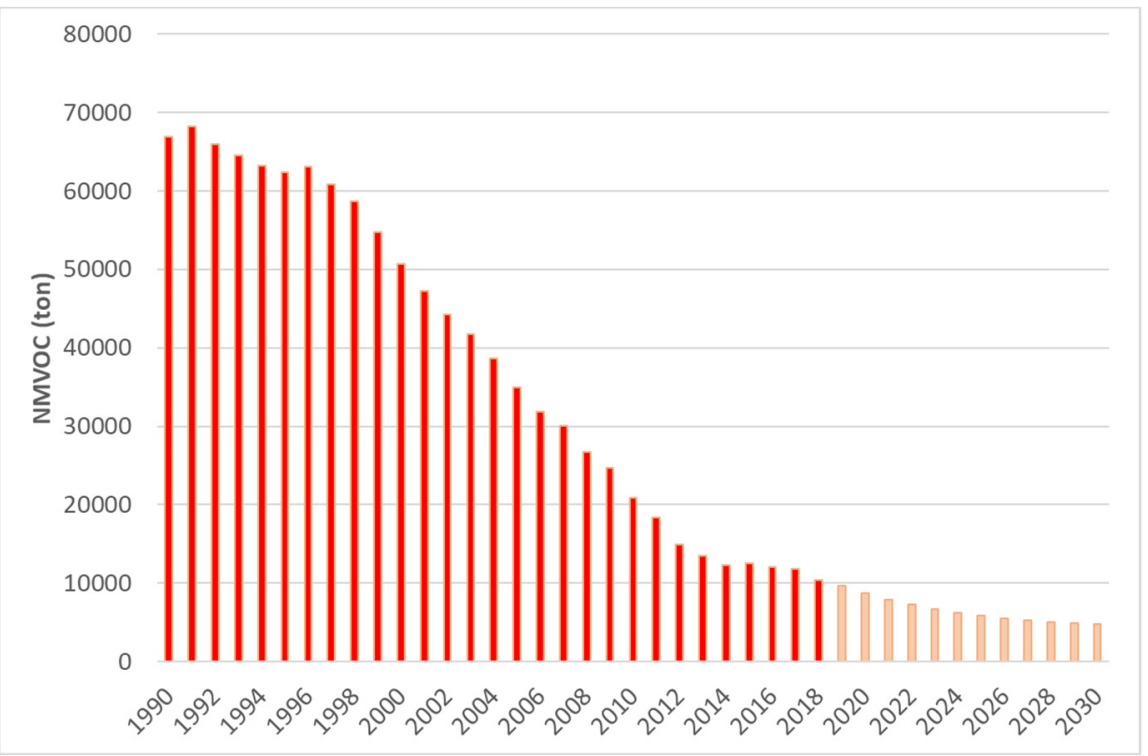

Figure 16. Total NMVOC (Non-methane volatile organic compounds) emissions from passenger cars in Greece for the period 1990-2030.

Figure 17 presents the total $\mathrm{CO}_{2}$ emissions from passenger vehicles in Greece for the period 1990-2030. One may see the different pattern in relation with pollutants, as $\mathrm{CO}_{2}$ emissions are strongly related to car fleet size. As vehicle numbers increased up to 2009, so did the emissions. It is noteworthy, that after 2014, when vehicle numbers started to climb, $\mathrm{CO}_{2}$ emissions did not increase as sharply as expected, as new and more efficient-fuel diesel vehicles entered the market under the EU's strict regulations.

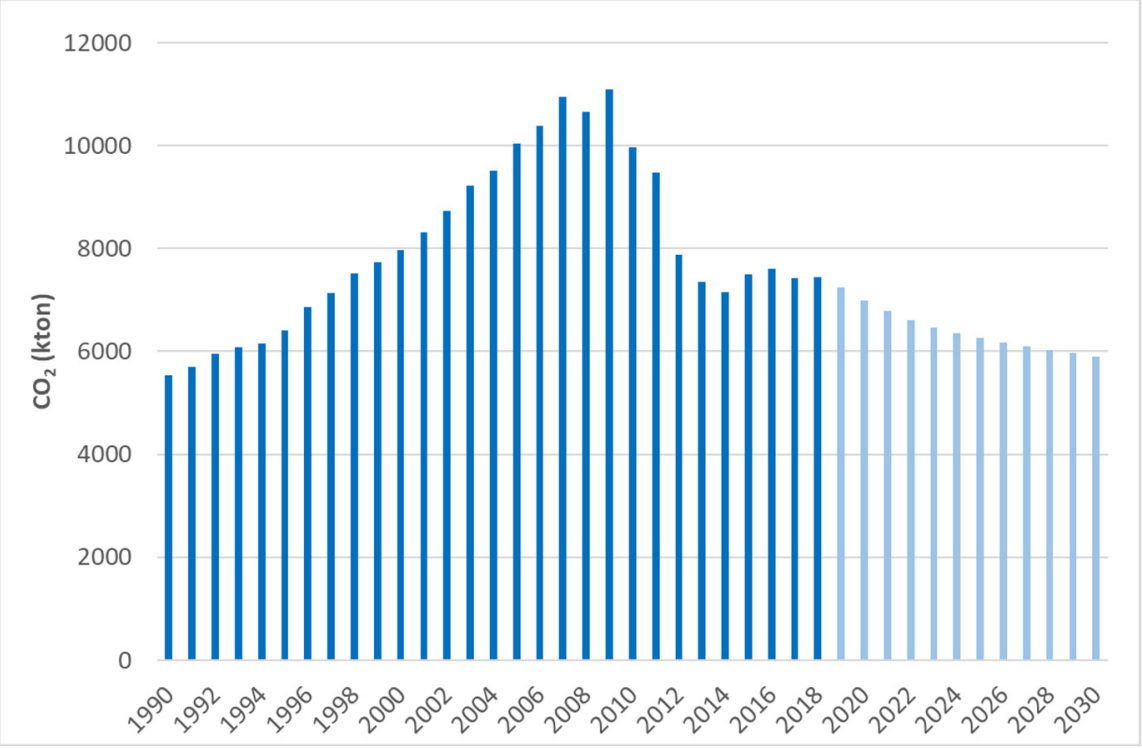

Figure 17. Total $\mathrm{CO}_{2}$ emissions from passenger cars in Greece for the period 1990-2030.

For the period between 1990 and 2018, there is an emission climb of more than $34 \%$, while by 2030 , the respective emissions are predicted to be higher than $6 \%$. Nevertheless, from 2018 to 2030, a total reduction of $20.6 \%$ is expected, albeit the vehicle fleet will only continue to increase in number. The above-mentioned observation is thoroughly explained in the discussion section. In 2030, almost 5.9 kton of $\mathrm{CO}_{2}$ will be emitted out of which $61.3 \%$ will be attributed to petrol vehicles, $20.4 \%$ to diesel vehicles, $5.6 \%$ to dual fuel vehicles, $10.6 \%$ to alternative fuel vehicles and $2.2 \%$ to PHEVs, while BEVs will have zero emissions. 
Finally, in Figure 18 the average values of emitted air pollutants and $\mathrm{CO}_{2}$ by vehicle are presented for the period 1990-2030. For each pollutant the value of $\mathrm{kg}$ per vehicle is calculated by dividing the sum of total emissions by the total vehicle number. Hence, it may be argued that in the course of time, reduction of air pollution is closely linked to the replacement of all ICE vehicles with BEVs.
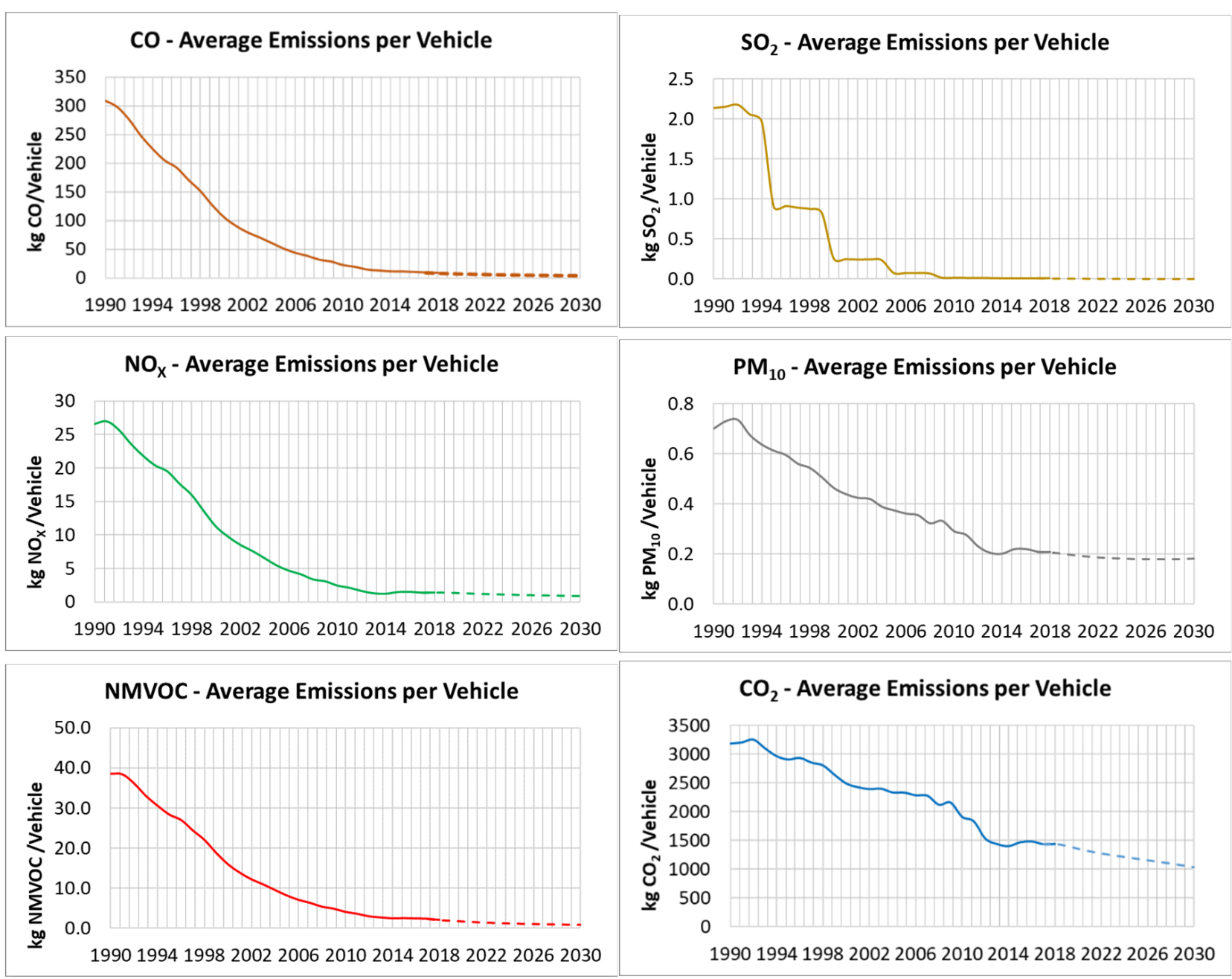

Figure 18. Average values of emitted air pollutants and $\mathrm{CO}_{2}$ by vehicle, for the tested period between 1990 and 2030, in Greece.

To sum up, Table 1 provides the reduction percentages for each pollutant in the period under consideration. For the period between 2018-2030, the largest improvement will occur in NMVOC with a reduction of $58.7 \%$ and the smallest improvement in $\mathrm{SO}_{2}$ with a reduction of $21.6 \%$. At this point, it should be noted that further improvement will come with the elimination of ICE vehicles. Within the forecasted period, $\mathrm{PM}_{10}$ is the pollutant with the least reduction, potentially partly due to non-exhaust emissions. In addition to this, with regard to $\mathrm{CO}_{2}$, it is clear that although the fleet emits less, there are opportunities for improvement, and this will only happen when more ICE vehicles are replaced by PHEVs and BEVs. 
Table 1. Average total emissions reductions per vehicle.

\begin{tabular}{cccc}
\hline Pollutant & $\mathbf{1 9 9 0 - 2 0 1 8}$ & $\mathbf{1 9 9 0 - 2 0 3 0}$ & $\mathbf{2 0 1 8 - 2 0 3 0}$ \\
\hline $\mathrm{CO}$ & $-97.2 \%$ & $-98.7 \%$ & $-51.1 \%$ \\
$\mathrm{SO}_{2}$ & $-99.7 \%$ & $-99.8 \%$ & $-21.6 \%$ \\
$\mathrm{NO}_{\mathrm{X}}$ & $-94.7 \%$ & $-96.5 \%$ & $-34.7 \%$ \\
$\mathrm{PM}_{10}$ & $-70.5 \%$ & $-74.2 \%$ & $-12.6 \%$ \\
$\mathrm{NMOC}^{\mathrm{CO}}$ & $-94.7 \%$ & $-97.8 \%$ & $-58.7 \%$ \\
\hline
\end{tabular}

Finally, in Table 2 the average emission reduction owing to BEVs penetration is presented for each pollutant. In the first row, total emissions per pollutant in 2030 are given, in accordance with the forecasting scenarios, while in the second row, total emissions assuming no BEV by 2030 are given. In addition to this, the average reduction percentage for each pollutant is calculated, highlighting the BEVs influence to total emissions, even if the penetration rate of EVs (Figure 9) is rather low.

Table 2. Emissions reductions owing to BEVs penetration in 2030.

\begin{tabular}{ccccccc}
\hline Year 2030 & $\mathbf{C O}$ & $\mathbf{S O}_{\mathbf{2}}$ & $\mathbf{N O}_{\mathbf{X}}$ & $\mathbf{P M}_{\mathbf{1 0}}$ & $\mathbf{N M V O C}$ & $\mathbf{C O}_{\mathbf{2}}$ \\
\hline $\begin{array}{c}\text { Forecasting Scenario Total } \\
\quad \text { Emissions (tn) }\end{array}$ & 23,731 & 30 & 5271 & 1030 & 4753 & $5,904,070$ \\
$\begin{array}{c}\text { Total Emissions (tn) } \\
\quad \text { without BEVs }\end{array}$ & 25,242 & 33 & 5779 & 1126 & 5040 & $6,427,682$ \\
$\begin{array}{c}\text { Reduction (\%) from BEVs } \\
\quad \text { Penetration }\end{array}$ & $-6.0 \%$ & $-8.5 \%$ & $-8.8 \%$ & $-8.6 \%$ & $-8.1 \%$ & $-5.7 \%$ \\
\hline
\end{tabular}

\section{Discussion}

The main objective of this study was to project the evolution of the local vehicle fleet in the medium-term, by different vehicle category, fuel type and vehicle technology and to produce detailed estimates and metrics on the anticipated air pollutants and $\mathrm{CO}_{2}$ emissions at the sector and vehicle level. The results show that the forecasted 2030 passenger vehicle fleet will be $68.8 \%$ petrol, $6.3 \%$ diesel, $10 \%$ dual fuel, $7.3 \%$ hybrid, $2.5 \%$ PHEV and $5.0 \%$ $\mathrm{BEV}$, and will contribute annually with $23.73 \mathrm{kton}$ of $\mathrm{CO}, 29.86$ ton of $\mathrm{SO}_{2}, 5.3 \mathrm{kton}$ of $\mathrm{NO}_{\mathrm{X}}$ 1.03 kton of $\mathrm{PM}_{10}, 4.75$ kton of NMVOC and 5904 kton of $\mathrm{CO}_{2}$.

The main culprit for most of these emissions will be petrol vehicles (specifically for: 74\%: $\mathrm{CO}, 63 \%: \mathrm{SO}_{2}, 49 \%: \mathrm{PM}_{10}, 82 \%$ : NMVOC and 61\%: $\mathrm{CO}_{2}$ ). However, diesel vehicles will be responsible for $67 \%$ of $\mathrm{NO}_{X}$ emissions despite the relatively small fleet. Clearly, "stick and carrot" policies are required to reduce the number of petrol and diesel vehicles in the fleet.

Even if all fossil fuel vehicles were to be replaced with BEVs powered by a low carbon electricity grid, the transport sector would still contribute particulate matter $\mathrm{PM}_{10}$ emissions. For non-exhaust emissions, COPERT accounts for several factors such as the speed-dependency of tyre and brake wear, mean vehicle travelling speed, brake/tyre wear fraction produced as dust fall particles, road abrasion (algorithm and emission factors for road surface wear), load for heavy-duty vehicles and others. For the last year of available data in this study (2018), $88 \%$ of $\mathrm{PM}_{10}$ was non-exhaust with the majority being emitted by vehicle tyres and brakes as well as tarmac friction. Non-exhaust particulate matter emissions have been shown to be strongly linked to vehicle mass [93]. Proliferation of heavier vehicles such as SUVs in recent years has led to increase in the share of non-exhaust emissions [94]. Electric vehicles can reduce brake PMs emissions remarkably, as they use electromagnetic brakes, but at the same time, they tend to wear tyres faster due to their higher weight. The latter can potentially be reduced with improved tyre compounds, which will likely become available once electric vehicles start gaining a significant market share. However, accurate estimation of where non-exhaust transport emissions might be 
headed with EVs proliferation is not straight-forward and depends on a range of uncertain parameters. Reducing emissions further requires increased use of public transport systems instead of private vehicles as well as cycling and walking.

Transport sector $\mathrm{CO}_{2}$ emissions tend to correlate with the fleet size and peaked in Greece in 2009. Subsequently gradually replacement of old petrol vehicles with new diesel vehicles led to a small reduction. This reduction was only slight because of the prevalence of sport utility vehicles (SUVs), a 2019 trend observed across Europe representing 38\% of sales at the time. SUVs are typically heavier, have more powerful engines and worse aerodynamics, leading to higher $\mathrm{CO}_{2}$ emissions per vehicle by approximately $10 \%$ compared to other passenger vehicles. Most new vehicles are heavier than their predecessors because of vehicle size, safety features and are significantly more complex in terms of cabling and sensor systems. The EU vehicle $\mathrm{CO}_{2}$ emission targets for 2025 and 2030 at $80 \mathrm{gr} / \mathrm{km}$ and $60 \mathrm{gr} / \mathrm{km}$ respectively will deliver impactful change to that end [95].

Looking into the vehicle fleet forecasting and its impact on expected emissions electrification has the most important role in emissions reduction. Given the expected gradual fleet electrification, this leads to the expectation that transport emissions will be reduced substantially. Electricity grid decarbonisation will then become the focal point of transport emissions reduction [96-99]. The Greek electricity system is rapidly transformed with ongoing plans for retirement of lignite coal power plants in 2028 and aggressive growth for renewable energy and natural gas plants within the 2020s. Improvements are also being made in power supply security, accessibility and sustainability [100]. Greece has committed [65] to ambitious targets for greenhouse gas emissions reduction and achieving net zero emissions by 2050. As a mid-term target for 2030 greenhouse gas emissions in Greece will be reduced by $40 \%$ compared to base year 1990, and the role of renewable energy in electricity generation will reach $60 \%$.

The distance travelled per vehicle is expected to be reduced in the next few years. This will be partly driven by the aging fleet, which has been shown to result in a gradual reduction in the vehicle use factor. Moreover, and given current affordability concerns, it is not likely for vehicle replacement time to be reduced to a level that would impact on fleet age. Concurrently, there has been a consistent trend over the years for increased public transport systems, which have been improving steadily. Moreover, it is noteworthy that micro-mobility vehicles, such as e-scooters and others offer more options in replacing short car trips. Long-term it is likely that autonomous vehicles will gradually make private vehicles redundant, reducing motorisation rate, as they will be too expensive and inconvenient to keep. Finally, the population is aging [101] and population growth has significantly decelerated over the past few years and even appears to be reducing in several wealthy countries [102], therefore, not leading to a growing vehicle demand beyond 2030.

Further positive developments within and beyond the 2020s are planned for emissions control and reduction in Greece as they have been part of recent political discourse and outlined by the PM's public announcements [103]. Specifically, the sales of petrol and diesel vehicles will be banned in 2030 and by 2025 all new taxis in Greece's two largest cities, Athens and Thessalonica, will have to be zero emissions vehicles as will 1/3 of all hire vehicles across the country. Beyond transport, for areas where natural gas is available, new built properties will not be equipped with oil boilers. Policy making in Greece is strongly aligned with EU Directives to achieve net zero emissions by 2050 [104].

During the last two years, the COVID-19 pandemic has had a significant impact in reducing urban transport use across most countries and Greece. The urban traffic reduction has led to significant, up to $80 \%$ urban air quality improvement in 2020 compared to 2019 in a range of large European cities [105]. Therefore, when electromobility takes on most of the urban private transport with parallel reduction of mileage driven by older private vehicles and increased use of public transport, it will lead to material air quality improvements. Beyond air pollution such changes will also impact significantly on the reduction of urban noise pollution which is largely driven by internal combustion engines. 


\section{Conclusions}

In conclusion, this study has performed an in-depth analysis of the Greek private vehicle fleet, its forecasted mix and the impact that will have on air pollutants. Established data have been used and expanded for vehicle subcategories and Brown's Double Simple Exponential Smoothing method was used for vehicle fleet forecasting to 2030. Expected emissions were estimated with the COPERT tier 2 and tier 3 approaches for each one of the 28 vehicle subcategories and for every specific pollutant.

Reduction in transport emissions might be the most promising area for urban air quality improvement. While the trajectory of such reductions relies strongly on technological improvements and user adoption, country and city level specificities remain a significant determinant, not only of what might be possible but mostly of the pace of change. Greece and specifically the capital city of Athens, with high population density and chronic lack of public transport infrastructure, are ripe for improvements. These are essential and will improve the livelihoods of large segments of the population. The classified, by vehicle subcategory, results are of high value to policy makers dealing with fleet characterization, anticipated fleet trends and associated emissions in producing nuanced policy.

As for other research, this study is not free of limitations. Firstly, the smoothing methodology has not been applied for electric vehicles, as their fleet in Greece before 2018 had barely reached 800 vehicles. Instead, data from the Energy Ministry were used. Secondly, forecasting was not adjusted for policy interventions, e.g., ban of petrol and diesel vehicle sales beyond 2030. Thirdly the average emission factors per vehicle, even though specialised on the specificities of vehicle subcategories, they will not be useful in extreme types of vehicle use, i.e., vehicles driven exclusively on highways, or those driven only for short distances. Lastly, several studies have implemented various factors besides fuel type to analyse consumer preferences [106-109] for the choice of vehicle type. Consumer preferences vary slightly from one study to another. However, apart from fuel type, which was used in this study, purchasing price and fuel cost are also important parameters. Additionally, the Hellenic Ministry of Environment and Energy finds that petrol and diesel fuel availability up to 2030 and beyond will be adequate to meet demand [65]. Furthermore, according to a study [110], for petrol and diesel fuels demand in 2030, in Greece, minimum additional measures will be needed affecting fuel price and therefore fuel availability. So, the availability of fuel up to 2030 was not considered as another factor in this study. Future research should focus on multiple hypothetical scenarios, adjusting data for the specificities of the New European driving cycle procedure WLTP (Worldwide harmonized Light vehicles Test Procedure) and its relevance to real world use, not least in relation to ratios of vehicle use in cities, frequency of stops and temperature. Specifically for Greece, the capital city of Athens is of high importance and warrants a specialised study as it hosts a very high share of the vehicle fleet and suffers from the air quality degradation that comes with it.

Author Contributions: Conceptualization, methodology and software, G.C.S.; validation and formal analysis, G.C.S., P.T.N., K.P.M. and K.J.C.; investigation, resources, data curation, writing-original draft preparation, G.C.S.; writing - review and editing, G.C.S. and K.J.C.; supervision, project administration, G.C.S., P.T.N., K.P.M. and K.J.C. All authors have read and agreed to the published version of the manuscript.

Funding: This research received no external funding.

Data Availability Statement: Restrictions apply to the availability of full data. Some of the data were obtained from [39] and are available [https:/ / www.emisia.com/shop/ (accessed on 15 November 2021)] with the permission of [39].

Conflicts of Interest: The authors declare no conflict of interest. 


\section{References}

1. Ortiz, A.G.; Guerreiro, C.; Soares, J.; European Environment Agency. Air Quality in Europe: 2020 Report; European Environment Agency: København, Denmark, 2020, ISBN 978-92-9480-292-7.

2. EEA. Greenhouse Gas Emissions from Transport in Europe-European Environment Agency. Available online: https://www.eea. europa.eu/data-and-maps/indicators/transport-emissions-of-greenhouse-gases-7/assessment (accessed on 10 October 2021).

3. European Commission. Urban Europe: Statistics on Cities, Towns and Suburbs: 2016 Edition; Statistical Office of the European Union Publications Office: Luxembourg, 2016.

4. Barter, P. Cars Are Parked 95\% of the Time. Let's Check! 2013. Available online: https://www.reinventingparking.org/2013/02/ cars-are-parked-95-of-time-lets-check.html (accessed on 27 October 2021).

5. Morris, D. Want to Know Why Uber and Automation Really Matter? Here's Your Answer. Available online: https:/ fortune. com/2016/03/13/cars-parked-95-percent-of-time/ (accessed on 27 October 2021).

6. Liu, L.; Miller, H.J.; Scheff, J. The impacts of COVID-19 pandemic on public transit demand in the United States. PLoS ONE 2020, 15, e0242476. [CrossRef] [PubMed]

7. SES. Transport Experts: “The Road Network in Athens Attica Was Saturated Even before the Pandemic". Available online: https: / / transportationgr.gr/sygkoinoniologoi-to-odiko-diktyo-sto-lekanopedio-itan-koresmeno-kai-prin-tin-pandimia/ (accessed on 10 November 2021).

8. EIA. EIA Projects Global Conventional Vehicle Fleet Will Peak in 2038-Today in Energy-U.S. Available online: https://www. eia.gov / todayinenergy / detail.php?id=50096 (accessed on 16 November 2021).

9. Dorocki, S.; Wantuch-Matla, D. Power Two-Wheelers as an Element of Sustainable Urban Mobility in Europe. Land 2021, 10, 618. [CrossRef]

10. Colvile, R.N.; Hutchinson, E.J.; Mindell, J.S.; Warren, R.F. The transport sector as a source of air pollution. Atmos. Environ. 2001, 35, 1537-1565. [CrossRef]

11. Belis, C.A.; Karagulian, F.; Larsen, B.R.; Hopke, P.K. Critical review and meta-analysis of ambient particulate matter source apportionment using receptor models in Europe. Atmos. Environ. 2013, 69, 94-108. [CrossRef]

12. Soret, A.; Guevara, M.; Baldasano, J.M. The potential impacts of electric vehicles on air quality in the urban areas of Barcelona and Madrid (Spain). Atmos. Environ. 2014, 99, 51-63. [CrossRef]

13. Ayalon, O.; Flicstein, B.; Shtibelman, A. Benefits of Reducing Air Emissions: Replacing Conventional with Electric Passenger Vehicles. JEP 2013, 4, 1035-1043. [CrossRef]

14. Spyropoulos, G.C.; Nastos, P.T.; Moustris, K.P. Performance of Aether Low-Cost Sensor Device for Air Pollution Measurements in Urban Environments. Accuracy Evaluation Applying the Air Quality Index (AQI). Atmosphere 2021, 12, 1246. [CrossRef]

15. Pistoia, G. Electric and Hybrid Vehicles: Power Sources, Models, Sustainability, Infrastructure and the Market, 1st ed.; Elsevier: Amsterdam, The Netherlands, 2010, ISBN 978-0-444-53565-8.

16. Kostopoulos, E.; Spyropoulos, G.; Christopoulos, K.; Kaldellis, J.K. Solar energy contribution to an electric vehicle needs on the basis of long-term measurements. Procedia Struct. Integr. 2018, 10, 203-210. [CrossRef]

17. Che, W.; Zheng, J.; Wang, S.; Zhong, L.; Lau, A. Assessment of motor vehicle emission control policies using Model-3/CMAQ model for the Pearl River Delta region, China. Atmos. Environ. 2011, 45, 1740-1751. [CrossRef]

18. Gonçalves, M.; Jiménez-Guerrero, P.; Baldasano, J.M. High resolution modeling of the effects of alternative fuels use on urban air quality: Introduction of natural gas vehicles in Barcelona and Madrid Greater Areas (Spain). Sci. Total Environ. 2009, 407, 776-790. [CrossRef]

19. Stephens-Romero, S.; Carreras-Sospedra, M.; Brouwer, J.; Dabdub, D.; Samuelsen, S. Determining Air Quality and Greenhouse Gas Impacts of Hydrogen Infrastructure and Fuel Cell Vehicles. Environ. Sci. Technol. 2009, 43, 9022-9029. [CrossRef]

20. Liaquat, A.M.; Kalam, M.A.; Masjuki, H.H.; Jayed, M.H. Potential emissions reduction in road transport sector using biofuel in developing countries. Atmos. Environ. 2010, 44, 3869-3877. [CrossRef]

21. Baldasano, J.M.; Gonçalves, M.; Soret, A.; Jiménez-Guerrero, P. Air pollution impacts of speed limitation measures in large cities: The need for improving traffic data in a metropolitan area. Atmos. Environ. 2010, 44, 2997-3006. [CrossRef]

22. Jones, B.; Elliott, R.J.R.; Nguyen-Tien, V. The EV revolution: The road ahead for critical raw materials demand. Appl. Energy 2020, 280, 115072. [CrossRef]

23. Hopkins, J.L.; McKay, J. Investigating 'anywhere working' as a mechanism for alleviating traffic congestion in smart cities. Technol. Forecast. Soc. Change 2019, 142, 258-272. [CrossRef]

24. Sanchez, T.W. Exploring the Relationship between Combined Household Housing and Transportation Costs and Regional Economic Activity in Virginia. Land 2021, 10, 742. [CrossRef]

25. Valavanidis, A.; Vlachogianni, T.; Loridas, S.; Fiotakis, C. Atmospheric Pollution in Urban Areas of Greece and Economic Crisis. Trends in Air Quality and Atmospheric Pollution Data, Research and Adverse Health Effects. 2015. Available online: https: / / www.researchgate.net/publication/284415702 (accessed on 17 November 2021).

26. De Sousa Silva, C.; Viegas, I.; Panagopoulos, T.; Bell, S. Environmental Justice in Accessibility to Green Infrastructure in Two European Cities. Land 2018, 7, 134. [CrossRef]

27. Symeonidis, P.; Ziomas, I.; Proyou, A. Emissions of air pollutants from the road transport sector in Greece: Year to year variation and present situation. Environ. Technol. 2003, 24, 719-726. [CrossRef] [PubMed] 
28. IEA. EMEP/CORINAIR Atmospheric Emission Inventory Guidebook. Available online: https://www.eea.europa.eu/ publications/EMEPCORINAIR/page005.html (accessed on 17 November 2021).

29. Poupkou, A.; Symeonidis, P.; Ziomas, I.; Melas, D.; Markakis, K. A Spatially and Temporally Disaggregated Anthropogenic Emission Inventory in the Southern Balkan Region. Water Air Soil Pollut. 2007, 185, 335-348. [CrossRef]

30. Symeonidis, P.; Ziomas, I.; Proyou, A. Development of an emission inventory system from transport in Greece. Environ. Model. Softw. 2004, 19, 413-421. [CrossRef]

31. Aleksandropoulou, V.; Lazaridis, M. Spatial Distribution of Gaseous And Particulate Matter Emissions in Greece. Water Air Soil Pollut. 2004, 153, 15-34. [CrossRef]

32. Aleksandropoulou, V.; Torseth, K.; Lazaridis, M. Atmospheric Emission Inventory for Natural and Anthropogenic Sources and Spatial Emission Mapping for the Greater Athens Area. Water Air Soil Pollut. 2011, 219, 507-526. [CrossRef]

33. Markakis, K.; Poupkou, A.; Melas, D.; Tzoumaka, P.; Petrakakis, M. A Computational Approach Based on GIS Technology for the Development of an Anthropogenic Emission Inventory of Gaseous Pollutants in Greece. Water Air Soil Pollut. 2010, 207, 157-180. [CrossRef]

34. Progiou, A.; Ziomas, I. Twenty-Year Road Traffic Emissions Trend in Greece. Water Air Soil Pollut. 2012, 223, 305-317. [CrossRef]

35. Progiou, A.G.; Ziomas, I.C. Road traffic emissions impact on air quality of the Greater Athens Area based on a 20year emissions inventory. Sci. Total Environ. 2011, 410-411, 1-7. [CrossRef]

36. Fameli, K.-M.; Assimakopoulos, V.D. The new open Flexible Emission Inventory for Greece and the Greater Athens Area (FEI-GREGAA): Account of pollutant sources and their importance from 2006 to 2012. Atmos. Environ. 2016, 137, 17-37. [CrossRef]

37. Fameli, K.M.; Assimakopoulos, V.D. Development of a road transport emission inventory for Greece and the Greater Athens Area: Effects of important parameters. Sci. Total Environ. 2015, 505, 770-786. [CrossRef]

38. Olivier, J.G.J.; Bouwman, A.F.; Van der Hoek, K.W.; Berdowski, J.J.M. Global air emission inventories for anthropogenic sources of NOx, NH3 and N2O in 1990. Environ. Pollut. 1998, 102, 135-148. [CrossRef]

39. Cai, H.; Xie, S. Estimation of vehicular emission inventories in China from 1980 to 2005. Atmos. Environ. 2007, 41, 8963-8979. [CrossRef]

40. Wang, H.; Chen, C.; Huang, C.; Fu, L. On-road vehicle emission inventory and its uncertainty analysis for Shanghai, China. Sci. Total Environ. 2008, 398, 60-67. [CrossRef]

41. Ramachandra, T.V.; Shwetmala. Emissions from India's transport sector: Statewise synthesis. Atmos. Environ. 2009, 43, 5510-5517. [CrossRef]

42. Spyropoulos, G.; Chalvatzis, K.; Paliatsos, A.; Kaldellis, J. Sulphur dioxide emissions due to electricity generation in the Aegean Islands: Real threat or overestimated danger. In Proceedings of the 9th International Conference on Environmental Science and Technology, Rhodes, Greece, 1-3 September 2005.

43. Bellasio, R.; Bianconi, R.; Corda, G.; Cucca, P. Emission inventory for the road transport sector in Sardinia (Italy). Atmos. Environ. 2007, 41, 677-691. [CrossRef]

44. Ministry of Infrastructure and Transport. Available online: https://www.yme.gov.gr/ (accessed on 1 November 2021).

45. HAS Hellenic Statistical Authority (HSA). Available online: https://www.statistics.gr/ (accessed on 1 November 2021).

46. European Commission Mobility and Transport Publications. Available online: https://transport.ec.europa.eu/media-corner/ publications_en (accessed on 29 October 2021).

47. ACEA. Vehicles in Use-Europe 2018; European Automobile Manufacturers Association: Brussels, Belgium, 2018.

48. ACEA. Vehicles in Use-Europe 2019; European Automobile Manufacturers Association: Brussels, Belgium, 2019.

49. ACEA. Vehicles in Use-Europe 2020; European Automobile Manufacturers Association: Brussels, Belgium, 2020.

50. ACEA. Vehicles in Use-Europe 2021; European Automobile Manufacturers Association: Brussels, Belgium, 2021.

51. AMVIR. Hellenic Association of Motor Vehicle Importers Representatives. Available online: https://seaa.gr/ (accessed on 1 November 2021).

52. Emisia. A Spin-Off Company (EMISIA) of the Aristotle University of Thessaloniki. Available online: https://www.emisia.com (accessed on 1 November 2021).

53. EEA. $\mathrm{CO}_{2}$ Emissions from New Passenger Cars-European Environment Agency. Available online: https://www.eea.europa.eu/ themes/transport/co2-emissions-from-new-passenger-cars (accessed on 1 November 2021).

54. Elkafoury, A.; Bady, M.; Aly, M.; Aly, F.; Negm, A. Emissions Modeling for Road Transportation in Urban Areas: State-of-Art Review. In Proceedings of the 23rd International Conference on-Environmental Protection is a Must, Alexandria, Egypt, 11-13 May 2013; Volume 23, p. 16.

55. Waka Kotahi NZ Transport Agency Vehicle Emissions Prediction Model. Available online: https://www.nzta.govt.nz/roads-andrail/highways-information-portal/technical-disciplines/air-quality-climate/planning-and-assessment/vehicle-emissionsprediction-model/ (accessed on 25 November 2021).

56. Elkafoury, A.; Negm, A.M.; Bady, M.; Aly, M.H.F. Review of transport emission modeling and monitoring in urban areasChallenge for developing countries. In Proceedings of the 2014 International Conference on Advanced Logistics and Transport (ICALT), Hammamet, Tunisia, 1-3 May 2014; pp. 23-28.

57. Wang, H.; McGlinchy, I. Review of vehicle emission modelling and the issues for New Zealand. In Proceedings of the Australasian Transport Research Forum, Auckland, New Zealand, 29 September-1 October 2009. 
58. Fath, B.D.; Jørgensen, S.E. (Eds.) Environmental Management Handbook; Applied Ecology and Environmental Management, 2nd ed.; CRC Press: Boca Raton, FL, USA, 2020, ISBN 978-1-00-305351-4.

59. Ntziachristos, L.; Gkatzoflias, D.; Kouridis, C.; Samaras, Z. COPERT: A European Road Transport Emission Inventory Model. In Information Technologies in Environmental Engineering; Athanasiadis, I.N., Rizzoli, A.E., Mitkas, P.A., Gómez, J.M., Eds.; Springer: Berlin/Heidelberg, Germany, 2009; pp. 491-504.

60. Zachariadis, T.; Samaras, Z. An Integrated Modeling System for the Estimation of Motor Vehicle Emissions. J. Air Waste Manag. Assoc. 1999, 49, 1010-1026. [CrossRef] [PubMed]

61. EEA. Road Transport 2019—European Environment Agency. Available online: https://www.eea.europa.eu/publications/emepeea-guidebook-2019/part-b-sectoral-guidance-chapters/1-energy/1-a-combustion/1-a-3-b-i/view (accessed on 26 November 2021).

62. Wesseling, J.H.; Faber, J.; Hekkert, M.P. How competitive forces sustain electric vehicle development. Technol. Forecast. Soc. Change 2014, 81, 154-164. [CrossRef]

63. Yuan, X.; Cai, Y. Forecasting the development trend of low emission vehicle technologies: Based on patent data. Technol. Forecast. Soc. Change 2021, 166, 120651. [CrossRef]

64. Onn, C.C.; Chai, C.; Abd Rashid, A.F.; Karim, M.R.; Yusoff, S. Vehicle electrification in a developing country: Status and issue, from a well-to-wheel perspective. Transp. Res. Part D Transp. Environ. 2017, 50, 192-201. [CrossRef]

65. HMEE. Greek National Energy and Climate Plan Report; Hellenic Ministry of Environment and Energy (HMEE): Athens, Greece, 2019. Available online: http:/ / www.opengov.gr/minenv/?p=10155 (accessed on 1 November 2021).

66. Chambers, J.C.; Mullick, S.K.; Smith, D.D. How to Choose the Right Forecasting Technique. Harvard Business Review. 1 July 1971. Available online: https:/ /hbr.org/1971/07/how-to-choose-the-right-forecasting-technique (accessed on 1 November 2021).

67. Wang, C.; Cai, W.; Lu, X.; Chen, J. $\mathrm{CO}_{2}$ mitigation scenarios in China's road transport sector. Energy Convers. Manag. 2007, 48, 2110-2118. [CrossRef]

68. Heaps, C.G. LEAP: The Low Emissions Analysis Platform. [Software Version: 2020.1.50]; Stockholm Environment Institute: Somerville, MA, USA, 2021.

69. Tsita, K.G.; Pilavachi, P.A. Decarbonizing the Greek road transport sector using alternative technologies and fuels. Therm. Sci. Eng. Prog. 2017, 1, 15-24. [CrossRef]

70. Kouridis, C.; Vlachokostas, C. Towards decarbonizing road transport: Environmental and social benefit of vehicle fleet electrification in urban areas of Greece. Renew. Sustain. Energy Rev. 2022, 153, 111775. [CrossRef]

71. Evans, J.R. Statistics, Data Analysis, and Decision Modeling, 3rd ed.; Pearson/Prentice Hall: Hoboken, NJ, USA, 2007, ISBN 978-0-13188609-4.

72. Agiakloglou, C.; Oikonomou, G. Methods of Forecasting and Analysis of Decisions, 3rd ed.; Benou: Athens, Greece, 2019, ISBN 978960-359-146-7.

73. Brown, R.G. Smoothing, Forecasting and Prediction of Discrete Time Series; Dover Publications: Mineola, NY, USA, 2004, ISBN 978-0486-49592-7.

74. Choi, J.; Roberts, D.C.; Lee, E.; Choi, J.; Roberts, D.C.; Lee, E. Forecast of $\mathrm{CO}_{2}$ Emissions From the U.S. Transportation Sector: Estimation From a Double Exponential Smoothing Model. J. Transp. Res. Forum 2014, 53, 63-81. [CrossRef]

75. Chiang, C.-Y.; Lin, W.T.; Suresh, N.C. An empirically-simulated investigation of the impact of demand forecasting on the bullwhip effect: Evidence from U.S. auto industry. Int. J. Prod. Econ. 2016, 177, 53-65. [CrossRef]

76. De la Fuente-Mella, H.; Paz-Cruz, A.; Conover, R.; Khan, A. Forecasting of Financial Series for the Nevada Department of Transportation Using Deterministic and Stochastic Methodologies. Procedia Manuf. 2015, 3, 3317-3324. [CrossRef]

77. Pegkas, P. Government Debt and Economic Growth. A Threshold Analysis for Greece. Peace Econ. Peace Sci. Public Policy 2019, 25, 20180003. [CrossRef]

78. Yükseltürk, A.; Wewer, A.; Bilge, P.; Dietrich, F. Recollection center location for end-of-life electric vehicle batteries using fleet size forecast: Scenario analysis for Germany. Procedia CIRP 2021, 96, 260-265. [CrossRef]

79. Talluri, G.; Grasso, F.; Chiaramonti, D. Is Deployment of Charging Station the Barrier to Electric Vehicle Fleet Development in EU Urban Areas? An Analytical Assessment Model for Large-Scale Municipality-Level EV Charging Infrastructures. Appl. Sci. 2019, 9, 4704. [CrossRef]

80. Azarafshar, R.; Vermeulen, W.N. Electric vehicle incentive policies in Canadian provinces. Energy Econ. 2020, 91, 104902. [CrossRef]

81. Shafiei, E.; Dauphin, R.; Yugo, M. Optimal electrification level of passenger cars in Europe in a battery-constrained future. Transp. Res. Part D Transp. Environ. 2022, 102, 103132. [CrossRef]

82. Eurostat. Eurostat Regional Yearbook; Statistical Books; European Commision: Luxembourg, 2016, ISBN 978-92-79-60090-6.

83. EEA. Size of the Vehicle Fleet in Europe-European Environment Agency. Available online: https://www.eea.europa.eu/dataand-maps/indicators/size-of-the-vehicle-fleet/size-of-the-vehicle-fleet-10 (accessed on 8 December 2021).

84. Triantafyllopoulos, G.; Dimaratos, A.; Ntziachristos, L.; Bernard, Y.; Dornoff, J.; Samaras, Z. A study on the $\mathrm{CO}_{2}$ and $\mathrm{NOx}$ emissions performance of Euro 6 diesel vehicles under various chassis dynamometer and on-road conditions including latest regulatory provisions. Sci. Total Environ. 2019, 666, 337-346. [CrossRef]

85. Nanaki, E.A.; Koroneos, C.J.; Xydis, G.A.; Rovas, D. Comparative environmental assessment of Athens urban buses-Diesel, CNG and biofuel powered. Transp. Policy 2014, 35, 311-318. [CrossRef] 
86. Suarez-Bertoa, R.; Valverde, V.; Clairotte, M.; Pavlovic, J.; Giechaskiel, B.; Franco, V.; Kregar, Z.; Astorga, C. On-road emissions of passenger cars beyond the boundary conditions of the real-driving emissions test. Environ. Res. 2019, 176, 108572. [CrossRef] [PubMed]

87. Vojtíšek-Lom, M.; Beránek, V.; Klír, V.; Jindra, P.; Pechout, M.; Voříšek, T. On-road and laboratory emissions of $\mathrm{NO}, \mathrm{NO}_{2}$, $\mathrm{NH}_{3}$, $\mathrm{N}_{2} \mathrm{O}$ and $\mathrm{CH}_{4}$ from late-model EU light utility vehicles: Comparison of diesel and CNG. Sci. Total Environ. 2018, 616-617, 774-784 [CrossRef] [PubMed]

88. Holmén, B.A.; Ayala, A. Ultrafine PM Emissions from Natural Gas, Oxidation-Catalyst Diesel, and Particle-Trap Diesel HeavyDuty Transit Buses. Environ. Sci. Technol. 2002, 36, 5041-5050. [CrossRef]

89. Giechaskiel, B. Solid Particle Number Emission Factors of Euro VI Heavy-Duty Vehicles on the Road and in the Laboratory. Int. J. Environ. Res. Public Health 2018, 15, 304. [CrossRef] [PubMed]

90. Ntziachristos, L.; Samaras, Z. EMEP/EEA Air Pollutant Emission Inventory Guidebook, Emep, COPERT 5.5, Guidebook. 2019. Available online: https://www.eea.europa.eu/publications/emep-eea-guidebook-2019/part-b-sectoral-guidance-chapters/1energy/1-a-combustion/1-a-3-b-i/at_download/file (accessed on 1 November 2021).

91. EU. Regulation (EU) 2019/631 of the European Parliament and of the Council of 17 April 2019 Setting CO2 Emission Performance Standards for New Passenger Cars and for New Light Commercial Vehicles, and Repealing Regulations (EC) No $443 / 2009$ and (EU) No 510/2011. 2019. Available online: https:/ / www.eea.europa.eu/ims/co2-performance-of-new-passenger (accessed on 1 November 2021).

92. EU. Regulation (EC) No 443/2009 of the European Parliament and of the Council of 23 April 2009 Setting Emission Performance Standards for New Passenger Cars as Part of the Community's Integrated Approach to Reduce CO2 Emissions from Light-Duty Vehicles. 2009. Available online: https:/ / www.eea.europa.eu/ims/co2-performance-of-new-passenger (accessed on 1 November 2021).

93. Oroumiyeh, F.; Zhu, Y. Brake and tire particles measured from on-road vehicles: Effects of vehicle mass and braking intensity. Atmos. Environ. X 2021, 12, 100121. [CrossRef]

94. Jeong, C.-H.; Traub, A.; Huang, A.; Hilker, N.; Wang, J.M.; Herod, D.; Dabek-Zlotorzynska, E.; Celo, V.; Evans, G.J. Long-term analysis of PM2.5 from 2004 to 2017 in Toronto: Composition, sources, and oxidative potential. Environ. Pollut. 2020, 263, 114652. [CrossRef]

95. EEA. $\mathrm{CO}_{2}$ Performance of New Passenger Cars in Europe. Available online: https://www.eea.europa.eu/ims/co2-performanceof-new-passenger (accessed on 9 December 2021).

96. Spyropoulos, G.; Petridou, K.; Liaros, S.; Kaldellis, J.K. Real World Driving Energy Consumption and Air Pollution Implications of Decarbonizing the Greek Transport Sector. In Proceedings of the 1st International Conference Energy in Transportation 2016 , EinT2016, Athens, Greece, 12 November 2016.

97. Spyropoulos, G.; Emmanouilidis, M.; Kaldellis, J.K. Investigating the long-term environmental performance of the Greek electricity sector on the basis of SO2 emissions. In Proceedings of the 12th International Conference on Environmental Science and Technology (CEST2011), Rhodes, Greece, 8-10 September 2011.

98. Kaldellis, J.; Spyropoulos, G.; Liaros, S. Supporting Electromobility in Smart Cities Using Solar Electric Vehicle Charging Stations. In Mediterranean Green Buildings \& Renewable Energy; Springer: Cham, Switzerland, 2017; pp. 501-513.

99. Kostopoulos, E.D.; Spyropoulos, G.C.; Kaldellis, J.K. Real-world study for the optimal charging of electric vehicles. Energy Rep. 2020, 6, 418-426. [CrossRef]

100. Worldenergy WEC. Energy Trilemma Index Tool. Available online: https://trilemma.worldenergy.org/\#!/ energy-index (accessed on 9 December 2021).

101. Eurostat Population Structure and Ageing. Available online: https:/ / ec.europa.eu/eurostat/statistics-explained/index.php? title=Population_structure_and_ageing (accessed on 5 January 2022).

102. Eurostat Population and Population Change Statistics. Available online: https:/ / ec.europa.eu/eurostat/statistics-explained/ index.php?title=Population_and_population_change_statistics (accessed on 5 January 2022).

103. European Union. Regulation (EU) 2021/1119 of the European Parliament and of the Council of 30 June 2021 Establishing the Framework for Achieving Climate Neutrality and Amending Regulations (EC) No 401/2009 and (EU) 2018/1999 ('European Climate Law'); European Union: Maastricht, The Netherlands, 2021; Volume 243.

104. European Commission. A European Green Deal. Available online: https://ec.europa.eu/info/strategy/priorities-2019-2024/ european-green-deal_en (accessed on 15 October 2021).

105. Cárcel-Carrasco, J.; Pascual-Guillamón, M.; Salas-Vicente, F. Analysis on the Effect of the Mobility of Combustion Vehicles in the Environment of Cities and the Improvement in Air Pollution in Europe: A Vision for the Awareness of Citizens and Policy Makers. Land 2021, 10, 184. [CrossRef]

106. Kim, K.; Lee, J.; Kim, J. Can liquefied petroleum gas vehicles join the fleet of alternative fuel vehicles? Implications of transportation policy based on market forecast and environmental impact. Energy Policy 2021, 154, 112311. [CrossRef]

107. Byun, H.; Shin, J.; Lee, C.-Y. Using a discrete choice experiment to predict the penetration possibility of environmentally friendly vehicles. Energy 2018, 144, 312-321. [CrossRef]

108. Choi, H.; Shin, J.; Woo, J. Effect of electricity generation mix on battery electric vehicle adoption and its environmental impact. Energy Policy 2018, 121, 13-24. [CrossRef] 
109. Kim, I.; Kim, J.; Lee, J. Dynamic analysis of well-to-wheel electric and hydrogen vehicles greenhouse gas emissions: Focusing on consumer preferences and power mix changes in South Korea. Appl. Energy 2020, 260, 114281. [CrossRef]

110. Aklilu, A.Z. Gasoline and diesel demand in the EU: Implications for the 2030 emission goal. Renew. Sustain. Energy Rev. 2020, 118, 109530. [CrossRef] 